\title{
Does Industrialization Affect Segregation? Evidence from Nineteenth-Century Cairo
}

\author{
Christophe Lévêque* Mohamed Saleh* \\ This version: May 26, 2017 \\ First draft: November 7, 2016
}

\begin{abstract}
We investigate the impact of state industrialization on residential segregation between Muslims and non-Muslims in nineteenthcentury Cairo using individual-level census samples from 1848 and 1868. We measure local segregation by a simple inter-group isolation index, where Muslims' (non-Muslims') isolation is measured by the share of Muslim (non-Muslim) households in the local environment of each location. We find that relative to locations that did not witness changes in the instance of industrialization, the opening of Cairo railway station in 1856 differentially increased Muslims' isolation from non-Muslims (conversely, decreased non-Muslims' isolation) in its proximity and that the closures of textiles firms in 18481868 differentially decreased it. The results are arguably driven by an "indirect" labor market mechanism, whereby state industrialized firms crowded in private-sector unskilled jobs that attracted greater net inflows of rural immigrants and unskilled workers who were predominantly Muslims.
\end{abstract}

Keywords: local segregation; industrialization; Middle East; railways; slums

JEL Codes: N35; R23

\footnotetext{
*Lévêque: Toulouse School of Economics. Saleh (Corresponding author): Toulouse School of Economics and Institute for Advanced Study in Toulouse, Manufacture des Tabacs, 21 Allée de Brienne, Building F, Office MF 524, Toulouse Cedex 6, F - 31015, FRANCE, mohamed.saleh@tse-fr.eu. We are grateful to Ran Abramtizky, the co-editor of Explorations in Economic History, and two anonymous referees for their excellent comments. We benefited from conversations with Leah Boustan, Philippe de Donder, Sylvain Chabé-Ferret, Joseph Ferrie, Julie Lassébie, Jordanna Matlon, Dimitris Pipinis, Karine Van Der Straeten, and Noam Yuchtman. The attendees of our presentations at TSE, IAST, EHESS-Toulouse, University of Barcelona, and University of Rennes, all provided us with useful comments. Saleh gratefully acknowledges the financial support from the ANR-Labex IAST. All errors are ours.
} 
"Over the past thirty years Europe's influence has transformed Cairo. Now we are civilized," Ismail, Khedive of Egypt (1863-79) (Raymond, 1993, p. 309).

\section{Introduction}

Many cities, such as Chicago, Baghdad, Beirut, Belfast, and Jerusalem, are segregated by ethnicity or religion. It has been documented that residential segregation has adverse effects on socioeconomic and political development, including socioeconomic outcomes of minorities (Cutler and Glaeser, 1997; Collins and Margo, 2000), provision of public goods (Trounstine, 2016), social capital (Uslaner, 2012), and inter-group conflicts (Field et al., 2008; Corvalan and Vargas, 2015). Perhaps motivated by the effects of segregation, scholars have long investigated its underlying causes, especially when segregation is not dictated by law but is rather an outcome of people's residential choices (Schelling, 1971; Card et al., 2008). Among the causes that can alter people's residential choices, and hence residential segregation, demand-side shocks to the labor market have received special attention. For example, the "spatial mismatch hypothesis" emphasized how the relocation of firms to the suburbs of US cities was associated with increased segregation between whites, who moved to the suburbs, and blacks, who were left behind in the city center (Kain, 1968).

An older but related question that dates back to, at least, Engels (1845) and the Chicago School of Sociology (Park and Burgess, 1925; Wirth, 1928), is whether segregation increases with the onset of industrialization. The first Industrial Revolution (IR), a technological shift that increased output per worker in the secondary sector, caused a labor demand shock that triggered population movements both from outside and within cities. As these movements varied by ethno-religions group, due to inter-group occupational 
differences, they often impacted residential segregation in industrialized cities. Engels vividly described the working-class slums, often predominantly Irish, that emerged with industrialization in English cities where "hundreds and thousands of alleys and courts lined with houses too bad for anyone to live in." Later scholarship revealed that several English and US cities were ethnically segregated during the first IR, although the evidence is far from conclusive (U.S.: Pratt, 1911; Hershberg et al., 1979; Greenberg, 1981; Zunz, 1982) (Britain: Ward, 1975, 1980). ${ }^{1}$ But understanding the impact of industrialization on segregation is not only a matter of historical concern about the first IR though. The rapid industrialization in recent histories of many developing countries often created ethno-religious enclaves of poor rural immigrants who were cramped in marginalized slums in large cities. For example, segregation by caste and/or religion is quite prevalent in Indian cities and increased with industrialization (Mehta, 1969; Vithayathil and Singh, 2012). The same phenomenon was documented in Sub-Saharan Africa, the Middle East, Asia, and Latin America (see Massey, 2016, for a recent review).

This article revisits the question using evidence from an early program of state industrialization in nineteenth-century Egypt. Following a long medieval tradition, native non-Muslim minorities who constituted 7 percent of the population of nineteenth-century Cairo, Egypt's capital and largest city, were clustered in certain neighborhoods in the city. ${ }^{2}$ Inspired by the first IR, Muhammad Ali, Egypt's autonomous Ottoman viceroy in 1805-1848, and his successors, embarked on an ambitious state industrialization program that employed 8 percent of Cairo's population in 1848

\footnotetext{
${ }^{1}$ Dennis (1986) estimates residential dissimilarity index between Irish and non-Irish populations in nineteenth-century England at 48-50 percent in Cardiff (1851), 50-55 percent in Liverpool (1871), and 56-78 percent in Hull (1851). Warner (1968) estimates dissimilarity between blacks and non-blacks in 1860 Philadelphia at 47 percent. These values are generally considered "moderate" segregation (Cutler et al., 1999).

${ }^{2}$ There was residential segregation within non-Muslims, across Coptic Christians, non-Coptic Christians (Armenians, Levantines, Greeks), and Rabbinic and Karaite Jews.
} 
and 3 percent in $1868 .{ }^{3}$ Between 1816 and 1848, the program focused on creating state manufacturing firms (mostly, textiles, military, paper and printing industries). However, as many of Ali's firms (especially, textiles) closed down after 1848, Ali's successors in 1848-1879 switched their efforts in the program's second wave to transportation and communications firms (railways, steam navigation, and telegraph) (Saleh, 2015). Although the program did not generate a permanent shift of the labor force from the primary to the secondary sector, nor Modern Economic Growth (MEG) (i.e. sustainable growth in GDP per capita), it shared a certain feature with the first IR in that it created a technical shift within the secondary sector. Compared to Egypt's private firms in this sector, state industrialized firms were (a) larger, (b) exhibited greater division of labor, and (c) more mechanized (attempted to imitate first-IR technologies of production). These common features, we argue, justify characterizing Egypt's program as "industrialization," especially in light of the recent revisionist literature on the first IR (see the historical background section).

The objective of this article is hence to examine whether Egypt's state industrialization affected residential segregation between Muslims and nonMuslims in Cairo at both the city level and across neighborhoods within the city. There are a few distinguishing features of the Egyptian context that arguably make it suitable to address this question. (1) Egypt's industrialization was a well-identified state decision, making it possible to observe the universe of industrialized firms (private firms did not industrialize) and thus (potentially) identify their impact on segregation. By contrast, industrialization during the first IR was a choice made by individual firms that is both more difficult to observe, and to identify its effects. (2) Unlike public policies that target residential segregation, the objective of Egypt's pro-

\footnotetext{
${ }^{3}$ This is the percentage out of Cairo's employed male population that is at least 15 years old based on the authors' calculations from the 1848 and 1868 population census samples. See the data section for details.
} 
gram was to maximize state revenues, and so its effects on segregation, if any, were unintended. This makes our case study more suitable to examine the spontaneous evolution of segregation in response to industrialization. (3) The segregation literature mostly relies on aggregate-level geographic information (e.g. US census tract) that only allows measuring segregation at an even more aggregated level (e.g. the city level). But with these measures, it is not possible to examine the local effects of industrialization. To the contrary, our study is perhaps the first to use individual-level geo-referenced data to examine the local impact of industrialization. (4) Medieval observers long documented that Middle Eastern cities, including Cairo, were segregated along religious lines, and inter-religious urban conflicts are a recurring phenomenon until today. Hence, Cairo is perhaps a suitable context to study religious segregation and how it may have been altered (unintentionally) by industrialization experiments. In this respect, our study is the first to examine local segregation in a nineteenth-century city outside North America and Western Europe. (5) Egypt witnessed a large urbanization wave, especially before $1848 .{ }^{4}$ Hence, the context is to an extent relevant to the recent experiences of developing countries.

In order to examine this question, we employ a novel data source, individual-level population census samples from 1848 and 1868 that were recently digitized from the original manuscripts at the National Archives of Egypt (Saleh, 2013). These are two of the earliest censuses from any non-Western country to include information on every household member including females, children, and slaves. More important for the purpose of this article, the census samples include the street address of each household, which allows us to geocode the samples at the street level. The censuses also report religion, occupation, and if an individual works in a state firm,

\footnotetext{
${ }^{4}$ About 36 and 71 percent of Cairo's and Alexandria's populations respectively in 1848 were born outside the city, although the percentages dropped down in 1868 to 16 and 34 percent.
} 
among other demographic information. We then merge the samples, aggregated to the household level, with a dataset on locations of large state manufacturing, transportation, and communications firms that operated in each of 1848 and 1868, geocoded at the street level, that we constructed from the census samples and historical sources. ${ }^{5}$

Residential segregation between ethno-religious groups is, by definition, a function of the spatial distribution of group populations within the city, and so it will be impacted if the population of one or more groups changes differentially across neighborhoods. Industrialization can trigger groupspecific population movements, and hence impacts segregation, via several mechanisms. In the absence of legal restrictions on residential choice, individuals may choose where to live based on (1) the commuting cost to their workplace, (2) amenities in the local neighborhood, and (3) a preference for living close to one's own group. ${ }^{6}$ Industrialized firms may directly alter the first two factors. On the one hand, these firms create a labor demand shock that may attract workers to live in their proximity in order to save on commuting cost. This could be either directly via employing people to work in the firm, or indirectly via crowding in, or crowding out, privatesector jobs in their proximity. For example, textiles firms may crowd out private spinners and weavers. On the other hand, industrialization may affect the level of amenities via externalities. For example, some firms are noisy or harmful for public health. The two effects may vary by religious group because of inter-group differences in occupations and preferences for amenities. Furthermore, the two effects may be enhanced, or rather miti-

\footnotetext{
${ }^{5}$ We focus on segregation between households, because the share of mixed-religion households is less than one percent in each census. Those are almost all households with servants or slaves of a different religion and not mixed-religion couples.

${ }^{6}$ Residential choice may also depend on relocation costs (including cost of housing). We abstract from this factor because (a) we do not observe housing prices, and (b) about 16 percent of Cairo's housing market in 1848 was comprised of low-status dwellings (courtyards, huts, production sites), which implies that relocation costs were perhaps low even among the poor.
} 
gated, by an individual's taste for segregation. For example, holding else constant, a firm that is located in a non-Muslim concentration neighborhood may attract other non-Muslims but may have less of an impact on Muslims, who may prefer instead to reside close to their co-religionists.

We first document that Cairo was highly segregated in both 1848 and 1868 and that the city-level segregation remained almost unchanged during that period, suggesting that the change in state industrialization in 18481868 had little of an effect on the overall segregation in the city. According to the dissimilarity index, 79-82 percent of Cairo's population had to move in order to have an equal share of non-Muslims in every neighborhood. According to the isolation index, the average Muslim household had 96-97 percent Muslims in her neighborhood. Those figures are much higher than English and US cities during the first IR, and are in fact on par with US cities at the peak of segregation in the 1970s (Cutler et al., 1999).

We then examine if large state industrialized firms impacted segregation at a finer geographic level. We measure local segregation by a simple intergroup isolation index, where Muslims' (non-Muslims') isolation is measured by the share of Muslim (non-Muslim) households in the local environment of each location. This captures how likely it is for households at a given location to interact with their own religious group within their immediate neighborhood. The index is symmetric across Muslims and non-Muslims: an increase in Muslims' isolation from non-Muslims implies a decrease in non-Muslims' isolation from Muslims and vice versa. Because we do not observe the same households in 1848 and 1868, we construct a panel dataset of locations that are observed in both years. We then exploit the crosslocation variation in the change in the instance of state industrialization between 1848 and 1868 that occurred within a 500-meters radius from each location. In this specification, the treatment group consists of two types of locations: (1) those that did not have in their proximity any large state 
firms in 1848 but witnessed the opening of at least one large firm by 1868 (locations close to Cairo railway station), and (2) those that had at least one large state firm in 1848 but witnessed the closures of all these firms by 1868 (locations close to two large textiles firms). The control group, on the other hand, consists of locations that did not witness changes in the instance of industrialization during that period. Those are of two types: (3) those that had in their proximity at least one large firm in both 1848 and 1868, and (4) locations that did not have any large firms in either 1848 or 1868 . While this specification allows us to control for time-invariant characteristics of locations, it relies on the assumptions that (a) there is reverse causality from (changes in) segregation to industrialization, and (b) there are no other location-specific time-varying characteristics that are driving both industrialization and segregation. Historical evidence suggests that both the location of the railway station and the survival of textiles firms in certain locations but not others, were decided on technical grounds and not based on preferences and/or characteristics of the local populations in Cairo's neighborhoods. We also include a set of controls in order to capture some of the location-specific changes in 1848-1868. However, we are unable to completely rule out threats to our identification assumption.

We find that the opening of the railway station had the largest impact on segregation as it differentially increased Muslims' isolation from non-Muslims in its proximity by 11-16 percentage points compared to the control group. In a similar vein, the closures of textiles firms differentially decreased Muslims' isolation in its proximity by 2-5 percentage points. Because of the symmetry of the isolation index, the opposite effects hold with respect to non-Muslims' isolation. These effects are driven by differential movements of Muslim and non-Muslim households, where the railway station attracted greater net inflows of Muslims while the closures of textiles firms generated greater net Muslim outflows. We conduct a number of 
robustness checks including controlling for the change in the number of workers in state jobs (we show that the findings are due to state industrialized firms rather than any state job), using mixed-religion streets as an alternative segregation measure, re-defining the control group to include only locations that did not have any firms in their proximity in either 1848 or 1868, and correcting standard errors for spatial correlation.

We examine the mechanisms that may be driving these findings in more depth. We first estimate the impact of the change in industrialization on the change in number of households headed by state firm workers, rural immigrants, foreigners, unskilled workers, artisans, white-collar workers, and inhabitants of low-status dwellings. We then examine the correlation between each of these changes and our measure of isolation. The results suggest that the railway station attracted in its proximity greater net inflows of rural immigrants and unskilled workers, and that the closures of textiles firms generated greater net outflows of both groups. As Muslims were overrepresented among these two groups, the net effect in the case of the railway station was a differential increase in the number of Muslims and, hence, in Muslims' isolation (symmetrically, a decrease in non-Muslims' isolation), and the opposite effects in the case of textiles firms. More importantly, most of these unskilled workers and rural immigrants did not work in state industrialized firms (or any state job) but rather in private-sector jobs. We thus attribute our findings to an indirect labor market mechanism whereby state firms crowd in private-sector jobs that are more attractive to rural immigrants and unskilled workers. For example, the railways station crowded in drivers of animal-drawn vehicles; unskilled workers who were predominantly Muslims. Finally, the fact that the railway station and one of the textiles closures were located in non-Muslim concentration neighborhoods suggests that labor market considerations were likely more important than taste for segregation in residential choices, especially among the poor. 
The rest of the article is organized as follows. Section 2 reviews the literature. Section 3 provides a historical background. Section 4 describes the data. Section 5 documents the city-level segregation. We introduce the empirical analysis in section 6 . Section 7 concludes.

\section{Related Literature}

The article contributes to several lines of literature besides the literature on industrialization and segregation during the first IR. First, there is a vast literature on the causes of segregation (see Royuela and Vargas, 2010; Boustan, 2011, for recent reviews). One line of this literature examines the role of preferences and the "tipping effect" in driving segregation, both theoretically (Schelling, 1971; Pancs and Vriend, 2007), and empirically (Bayer et al., 2007; Card et al., 2008). Another line of this literature examines how public policies may affect segregation (Ananat and Washington, 2009; Ananat, 2011; Boustan, 2011; Bayer and McMillan, 2012; Banzhaf and Walsh, 2013). A third line of the literature, the so-called the "spatial mismatch hypothesis," examines the impact of relocation of firms on segregation (Kain, 1968, 1992; Hellerstein et al., 2008; Boustan and Margo, 2009). Our article is related to the three lines of literature as it examines the impact on segregation of the openings and closures of state firms, an example of public policies that alter characteristics of neighborhoods.

Second, the article is related to the old and vast literature on the measurement of segregation that dates back to Duncan and Duncan (1955), Massey and Denton (1988), and, more recently, Reardon and O'Sullivan (2004), Echenique and Fryer (2007), Reardon et al. (2008), Johnston et al. (2011), Mele (2013), and Östh et al. (2015). We draw on this literature in measuring spatial segregation at a fine geographic level.

Finally, the paper contributes to the growing historical geography liter- 
ature that employs geo-referenced historical data (DeBats and Lethbridge, 2005; Gilliland and Olson, 2010; Gilliland et al., 2011). An old medieval tradition described Cairo's urban space including the spatial distribution of its churches and synagogues (Al-Maqrizi, 2002; Mubarak, 1887). The modern literature on the subject often draws on these narratives (Raymond, 1973, 1993; Dridi, 2014, 2015). We are the first to employ geo-referenced census data to document changes in Cairo's urban history. We are also the first to link these changes to Egypt's nineteenth-century state industrialization program. In particular, due to data limitations, the (vast) literature on the program is qualitative and does not provide evidence on how the program may have affected the local population (Al-Gritli, 1952; Fahmy, 1954; Al-Hitta, 1967; Marsot, 1984; Owen, 2002; Saleh, 2015). We attempt to fill in the gap in the literature.

\section{Historical Background}

\subsection{Religious Residential Segregation in Cairo}

Nineteenth-century Cairo was spatially segregated between Muslims and non-Muslims (7 percent of the population in both 1848 and 1868). Coptic Christians, who constituted 65 percent of the non-Muslim population of Cairo, were spatially concentrated in certain neighborhoods in the city, and the same was true for non-Coptic Christians (20 percent) and Jews (15 percent). Cairo's segregation was not a mid-nineteenth-century phenomenon though as it has been documented in the early Islamic period (641-969) (Dridi, 2014), the Mamluk period (1250-1517) (Dridi, 2015), and the early 1800s (Jomard, 1829). 


\subsection{State Manufacturing, Transportation, and Com- munications Firms in 1816-1879}

A technological shift within the secondary sector occurred as Egypt embarked on a state industrialization program between 1816 and 1879. In 1816, Muhammad Ali Pasha, the autonomous Ottoman viceroy in 18051848, established the first textiles firm. That was followed by a series of firms in textiles (66 percent of employment in state firms), military (17 percent), and other industries including paper and printing (17 percent). Most firms were located in Cairo and Alexandria. In 1848, state manufacturing firms employed 8 percent of Cairo's employed adult male population. Nevertheless, many state manufacturing firms of the first wave (especially textiles) were closed down after 1848, due to the (macro-level) lack of skilled labor, the crude technology, the chronic fuel shortage, the upper limit imposed in 1841 on the army size (the raison d'être of the program), and the Anglo-Turkish Tariff Convention in 1838 that dissolved state monopolies.

The closures of many manufacturing firms of the first wave triggered Ali's successors to switch their efforts to transportation and communications in the second wave in 1848-1879. That was partially motivated by Europe's interest in developing trade routes in the Ottoman Empire. In 1854, the first railways line between Cairo and Alexandria was established and Cairo railway station was then opened in 1856. Other projects followed including the telegraph (1854) and steam navigation (1856 and 1863). The pace of state investment in the sector accelerated under the ambitious Khedive Ismail Pasha, Ali's grandson, who ruled from 1863 to 1879, and who expanded on the railways, telegraph, and steam navigation networks. As a result, state firms in 1868 employed 3 percent of Cairo's employed adult male population, less than half of their employment share in 1848, but 58 percent of state firm workers were now employed in transportation and 
communications, 22 percent in military, 17 percent in other industries, and only 3 percent in textiles. Despite its smaller size, the firms of the second wave were more likely to survive than those of the first wave; for example, the railways survived until today.

\subsection{Was Egypt's State Program "Industrialization"?}

Historians have long debated the extent to which Egypt's program in 18161879 can be described as "industrialization," in comparison to the first IR in Western Europe, North America, and Japan. The answer to this question naturally depends on the definition of industrialization one employs. ${ }^{7}$

The argument for describing Egypt's program as "industrialization" is based on the fact that it shared certain features with the first IR, which was, according to the recent revisionist literature (Shaw-Taylor and Wrigley, 2014), a technological shift in the secondary sector (especially, manufacturing) that increased output per worker. Egypt's program indeed triggered a technical shift in the secondary sector. First, Egypt's state firms were larger than private firms; they had a median size of 163 workers in 1848 and 60 workers in 1868, while the typical artisanal workshop had only 3.5-12.5 workers (Raymond, 1973, p. 222). Second, the larger firm size induced a greater division of labor within state firms. Third, state firms used more sophisticated technologies of production than private firms. They employed machines (copied or imported from Western Europe), in contrast to manual methods in artisanal (manufacturing) workshops and private transportation. And, unlike private firms that used human power, many state manufacturing firms in the first wave resorted to animal power in producing energy, whereas railways and steam navigation in the second wave resorted

\footnotetext{
${ }^{7}$ For example, historians such as Al-Gritli (1952), Fahmy (1954), Al-Hitta (1967), and Ghazaleh (1999) refer to Egypt's state firms during this period as "manufactories," and to the program as "industrialization." By contrast, Owen (2002) questions this characterization.
} 
to steam power. Evaluating whether this technical shift increased output per worker or not requires having systematic data on output and costs from the production side for both state and private firms (e.g. manufacturing census) which we currently do not have. But based on the variation in survival across state firms, even after the dissolution of state monopolies in 1838 , it is plausible that state firms might have varied in their relative productivity vis-à-vis the private sector. ${ }^{8}$

Despite these common features, there is a counter-argument that the program does not qualify as industrialization. First, Egypt's program did not trigger a (permanent) shift of the labor force from the primary to the secondary sector, and the primary sector continued to employ a high share (65 percent) of Egypt's population. ${ }^{9}$ Second, unlike the market-driven first IR, Egypt's firms were owned and run by the state and not by the private sector. Third, and perhaps most importantly, Egypt did not achieve "Modern Economic Growth" (MEG) during the nineteenth century. ${ }^{10}$

With this counter-argument in mind, is it precise to characterize Egypt's program as industrialization? We argue that the answer is yes. First, the share of the population that was employed in the primary sector in Conti-

\footnotetext{
${ }^{8}$ Military, paper, printing, transportation, and communications firms were all more likely to survive than textiles firms.

${ }^{9}(1)$ The 1848 and 1868 population census samples reveal that the male employment share of the secondary sector was stable between 1848 and 1868, whether in all Egypt (11 percent) or in Cairo (49-50 percent), despite the closure of many state manufacturing firms (of the first wave) in 1848-1868. (2) Consistent with what we know about the second wave, there was an employment shift within the secondary sector in 1848-1868 (observed in Cairo, but not in all Egypt), where the share of manufacturing, quarrying, and constructions declined from 44 to 41 percent, while the share of transport and communications increased from 6 to 8 percent. (3) We do not have data on the sectoral composition of male employment before 1848, let alone before Ali's program started in 1816. But if we take the sectoral composition in 1868 and the subsequent 1897 census, as a counterfactual for the pre-1816 distribution, it is plausible that the share of the secondary sector remained stable throughout the nineteenth century.

${ }^{10} \mathrm{MEG}$ can be defined as sustainable growth in real GDP per capita (say, at least 1-2 percent annually, on average, for a long period of time). The average annual growth rate of real GDP per capita in Egypt stood at a low level of 0.4 percent in 1820-70, in contrast to 1.1 percent in the U.S. and Western Europe, or 0.7 percent in neighboring Lebanon (where there was no similar program) over the same period (Pamuk, 2006).
} 
nental Europe during the first IR was not much lower than in Egypt, ${ }^{11}$ suggesting that there was a limited employment shift to the secondary sector during this period. ${ }^{12}$ Second, like the Egyptian program, the twentiethcentury industrialization programs of China, Soviet Union, and Eastern Europe were all state-run. Third, generating MEG is not a component of industrialization, but is rather an outcome that depends on the relative productivity of industrialized firms and their share in total output.

\section{Data}

Examining the impact of industrialization on segregation between religious groups in nineteenth-century Cairo requires having information on the location of state industrial firms along with the religious composition of neighborhoods at a fine geographic level. We employ a novel data source for this purpose, the 1848 and 1868 individual-level population census samples. These nationally-representative samples were digitized from the original Arabic manuscripts at the National Archives of Egypt at an 8-percent sampling rate in Cairo in each year (Saleh, 2013). The samples include information on religion, street address (street name and dwelling number), occupation, workplace (for workers in state firms), nationality, place of origin, dwelling type (e.g. house, hut, courtyard), and type of property rights on dwellings (e.g. private property, religious endowment or waqf).

We restrict our analysis to Cairo, where we employed the street address information to geo-locate each household in 1848 and 1868 using street names in current digital maps and information on locations of nineteenthcentury Cairo's streets in Mubarak (1887). The success rate of the geocod-

\footnotetext{
${ }^{11}$ The share of the primary sector in France, Italy, and Spain remained quite high (50-55 percent) as late as 1870 for France and 1910 for Italy and Spain.

${ }^{12}$ England witnessed an only slight increase in the secondary sector employment share (that was 4-times bigger than Egypt's) between 1710 and 1871 (Shaw-Taylor and Wrigley, 2014).
} 
ing process is 81 percent in 1848 and 87 percent in $1868 .{ }^{13}$

We combine the census samples with a dataset on locations of large state industrial firms in Cairo in 1848 and 1868 which we constructed as follows. We first used the information on workplace in the census samples that is available for all workers employed by the state. This allowed us to compile a comprehensive list of state firms that existed in Cairo in 1848 and 1868 (52 firms) and to estimate the employment size of each firm in each year. Second, we checked our list against the information on state firms provided by Sami (1928), Al-Gritli (1952), and Fahmy (1954). Third, we restricted the list to firms that had at least 10 workers in the sample in either 1848 or 1868 , i.e. about 125 workers in the population (sampling rate $=8 \%)(19$ firms). Finally, we geo-located large state firms using (a) information on location mentioned in the name of the firm, (b) historical information on locations of firms in the aforementioned sources, and (c) historical maps of Cairo that mapped certain firms. The dataset is shown in Table 1. While we cannot be entirely certain that we are not missing any large state firm in Cairo that existed in 1848 and 1868, the fact that, unlike the previous literature on the topic that relied on secondary sources, we are relying on the full population censuses of Cairo that record (from the viewpoint of the state administration) the workplace of every worker employed by the state (whether in an industrial firm or not), makes us relatively confident in our list. For one, our initial list includes many small state firms that are not recorded at all by the contemporary literature. For another, contrary to the historical literature that assumes that all state firms in textiles and military sectors closed down after 1838 or 1841, we find that many state firms survived not only in 1848 but even through 1868 .

\footnotetext{
${ }^{13}$ The success rate in Alexandria, the second largest city, was too low (33 percent) to include it in the analysis. This is likely due to the massive expansion of Alexandria since 1848 which altered street names.
} 


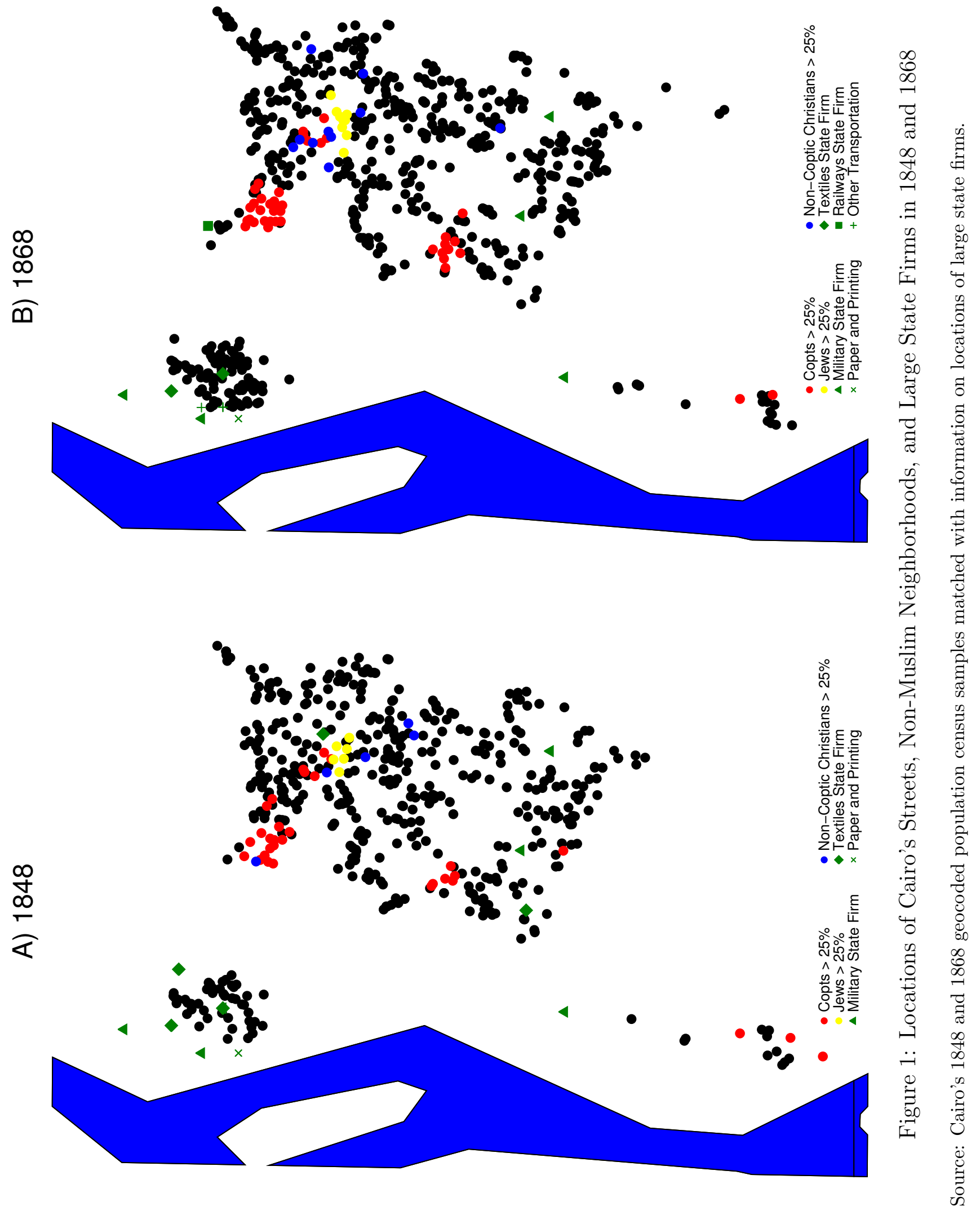


Table 1: Large State Industrial Firms in Cairo in 1848 and 1868

\begin{tabular}{llcc}
\hline \multicolumn{1}{c}{ Industry } & State Firm & Size in $\mathbf{1 8 4 8}$ & Size in $\mathbf{1 8 6 8}$ \\
\hline Military & Munitions (Old Cairo) & 413 & 190 \\
Military & al-Zuhurat (weapons) (Citadel) & 150 & 0 \\
Military & Cannons (Citadel) & 138 & 50 \\
Military & Guns (al-Hod al-Marsud) & 463 & 170 \\
Military & Rope-making (Bulaq) & 250 & 0 \\
Military & Arsenal (Bulaq) & 1825 & 10 \\
Military & Machines (Bulaq) & 188 & 50 \\
Paper and Printing & Bulaq printing house & 300 & 200 \\
Paper and Printing & Paper (Bulaq) & 125 & 10 \\
Textiles & Cotton textiles (al-Sayyida Zaynab) & 563 & 0 \\
Textiles & Cotton textiles (al-Khurunfish) & 1388 & 0 \\
Textiles & Linen textiles (Bulaq) & 463 & 20 \\
Textiles & Baize (Bulaq) & 250 & 0 \\
Textiles & Cotton textiles (al-Sabtiyah) & 375 & 0 \\
Textiles & Cotton textiles (Bulaq) & 913 & 100 \\
Transportation & al-Aziziya steam ships station & 0 & 210 \\
Transportation & al-Ingirariya steam ships station & 0 & 150 \\
Transportation & Railways station & 0 & 1000 \\
Communications & Telegraph station & 0 & 110 \\
\hline
\end{tabular}

Sources: The 1848 and 1868 census samples of Cairo and information on state firms in Sami (1928), Al-Gritli (1952), and Fahmy (1954).

Notes: The list is restricted to state industrial firms that had at least 10 workers in the population census sample in either 1848 or 1868.

In order to visualize the data, we plot the locations of geo-referenced streets that are observed in the population census samples and the large state firms in each of 1848 and 1868 in Figure 1. Each dot on the map represents the mean coordinates of a street, ${ }^{14}$ where the color reflects the share of non-Muslims in the street; red for streets where the share of Copts exceeds 25 percent, blue for non-Coptic Christians, yellow for Jews, with black dots being all remaining streets with a share of non-Muslims that is less than 25 percent. Notice that the plotted dots include all households in Cairo's census sample with a geo-referenced street. Cairo was divided into a main section and two suburbs, Bulaq and Old Cairo, located close to the Nile in the northwest and southwest ends respectively. Non-Muslim minorities were clustered in certain neighborhoods and their distribution

\footnotetext{
${ }^{14} \mathrm{We}$ are not able to employ the dwelling number in our geo-referencing procedure. This means that all households who reside in the same street are assigned the coordinates of the center of that street.
} 
remained largely stable between 1848 and 1868 .

Green locations on the map are the coordinates of large state firms (Table 1). In 1848, state textiles firms were in Bulaq, al-Khurunfish quarter in the northeast of Cairo, and al-Sayyida Zaynab quarter in the southwest of main Cairo. Military firms were concentrated in Bulaq and close to the citadel (the viceroy's palace) in the south. Two paper and printing firms were opened in Bulaq. By contrast, in 1868, only two firms in Bulaq survived. Military, paper, and printing firms mostly survived despite two military closures. A few transportation firms were opened: Cairo railway station in the northwest and other transportation and communications firms in Bulaq that comprised two steam ship stations and a telegraph station.

\section{City-Level Segregation in 1848 and 1868}

Did the openings and closures of state firms between 1848 and 1868 affect the city-level residential segregation between Muslims and non-Muslims in Cairo? In this section, we document the evolution of the city-level segregation using both the standard "aspatial" indexes of segregation, the dissimilarity and isolation indexes, and the more recent "spatial" measures.

\subsection{Measures of Segregation}

Two standard measures of segregation that are widely used in the literature are the dissimilarity and isolation indexes, which are computed as follows:

$$
\begin{gathered}
\text { Dissimilarity }_{t}=\frac{1}{2} \sum_{j=1}^{n}\left|\frac{\text { Muslim }_{j, t}}{\text { MuslimTotal }_{t}}-\frac{\text { NonMuslim }_{j, t}}{\text { NonMuslimTotal }_{t}}\right| \\
\text { Isolation }_{\text {Muslim }, t}=\sum_{j=1}^{n} \frac{\text { Muslim }_{j, t}}{\text { MuslimTotal }_{t}} \times \frac{\text { Muslim }_{j, t}}{\text { PopTotal }_{j, t}}
\end{gathered}
$$




$$
\text { Isolation }_{\text {NonMuslim }, t}=\sum_{j=1}^{n} \frac{\text { NonMuslim }_{j, t}}{\text { NonMuslimTotal }_{t}} \times \frac{\text { NonMuslim }_{j, t}}{\text { PopTotal }_{j, t}}
$$

where Muslim, NonMuslim and PopTotal are the numbers of Muslim households, non-Muslim households, and the total number of households respectively in location $j$ in year $t$. MuslimTotal and NonMuslimTotal are the total number of Muslim and non-Muslim households respectively in the city. The dissimilarity index gives the percentage of households who must move in order to obtain an equal share of non-Muslim households across all neighborhoods. The isolation index for Muslims (non-Muslims), on the other hand, gives the percentage of Muslim (non-Muslim) households in the neighborhood of the average Muslim (non-Muslim) household. Both indexes vary between 0 and 1 with 1 indicating perfect segregation.

Despite their simplicity, the measures suffer from a few caveats (Massey and Denton, 1988; Wong et al., 2007). First, they are sensitive to scale; they generally increase when measured at a smaller scale. Second, they are sensitive to the administrative boundaries that are used in defining neighborhoods, making it difficult to compare segregation across cities or in the same city over time. This is especially problematic in Cairo where the administrative boundaries of quarters (administrative units that are larger than streets but smaller than districts) changed between 1848 and 1868 . In order to address these concerns, and to be able to compare segregation in Cairo in 1848 and 1868, we first computed segregation using streets and districts (the units that are relatively stable across the two years). We then created "artificial neighborhoods" that are invariant over time and therefore permit a more meaningful comparison. ${ }^{15}$ We provide more details on the creation of artificial neighborhoods in section (B) of the online appendix.

A third and related caveat of the aspatial segregation indexes, as noted

\footnotetext{
${ }^{15}$ A small number of "artificial neighborhoods" are populated in only one of the two years and so we dropped those neighborhoods when we computed the indexes.
} 
by Reardon and O'Sullivan (2004), is that they do not take into account the proximity between neighborhoods. For example, a non-Muslim population that is concentrated in two neighborhoods would be differently segregated if the neighborhoods are, or are not, contiguous. Thus, in order to obtain a spatial view of segregation in the city, we computed the spatial versions of the dissimilarity and isolation indexes as suggested by Reardon and O'Sullivan (2004). The computation proceeds in two steps. We first count the number of households of Muslims, non-Muslims, and the total population in the local environment of (i.e. a circle around) each artificial neighborhood. We then use these population figures in calculating the dissimilarity and isolation indexes. We refer the reader to section (B) of the online appendix for further details on the computation of these indexes.

\section{$5.2 \quad$ Findings}

The results on the city-level segregation in Cairo in 1848 and 1868 are shown in Table 2. All measures of segregation suggest that Cairo was a highly segregated city in both 1848 and 1868 and that segregation remained almost unchanged during that period. According to the dissimilarity index measured across artificial neighborhoods, 79-82 percent of the population had to move in order to have an equal share of non-Muslim households in every neighborhood. In line with previous studies on segregation, we find that the dissimilarity index drops when it is measured across districts (which are larger than streets). The isolation index for Muslims indicates that the typical Muslim household lived in a street with 98 percent Muslims. The spatial measures of segregation show similar results.

These findings are probably not surprising because, at their peak, state firms recruited only 8 percent of Cairo's employed adult male population, which is perhaps too small to alter the overall segregation in the city. 
Table 2: Religious Residential Segregation in Cairo in 1848 and 1868

\begin{tabular}{lcccccccc}
\hline \hline Year & Neighborhoods & $\mathbf{N}$ & $\begin{array}{c}\text { Dissimilarity } \\
(\text { Aspatial })\end{array}$ & $\begin{array}{c}\text { Isolation } \\
(\text { Aspatial })\end{array}$ & $\begin{array}{c}\text { Diss } \\
(300 \mathrm{~m})\end{array}$ & $\begin{array}{c}\text { Iso } \\
(300 \mathrm{~m})\end{array}$ & $\begin{array}{c}\text { Diss } \\
(500 \mathrm{~m})\end{array}$ & $\begin{array}{c}\text { Iso } \\
(500 \mathrm{~m})\end{array}$ \\
\hline 1848 & Street & 499 & 0.9098 & 0.9823 & - & - & - & - \\
1868 & Street & 632 & 0.8682 & 0.9786 & - & - & - & - \\
& & & & & & & & - \\
1848 & District & 10 & 0.4871 & 0.9354 & - & - & - & - \\
1868 & District & 10 & 0.4796 & 0.9383 & - & - & - & - \\
& & & & & & & & \\
1848 & AN (1) & 110 & 0.8249 & 0.9666 & 0.7783 & 0.96 & 0.678 & 0.9518 \\
1868 & AN (1) & 110 & 0.8156 & 0.9686 & 0.7636 & 0.963 & 0.691 & 0.9521 \\
& & & & & & & & \\
1848 & AN (2) & 90 & 0.7918 & 0.9560 & 0.7116 & 0.9519 & 0.6289 & 0.9461 \\
1868 & AN (2) & 90 & 0.7990 & 0.9636 & 0.7468 & 0.9598 & 0.6646 & 0.9541 \\
\hline \hline
\end{tabular}

Source: The 1848 and 1868 geocoded household-level census samples of Cairo.

Notes: AN (1) refers to artificial neighborhoods that are populated in both 1848 and 1868 , where Cairo is divided into $25^{*} 25$ grid cells, whereas AN (2) refers to populated artificial neighborhoods in $20 * 20$ grid cells.

\section{Empirical Analysis}

Having documented that the city-level residential segregation between Muslims and non-Muslims in Cairo changed little between 1848 and 1868, we now proceed to the central question of this article, whether industrialization affected segregation at a finer geographic level. In this section, we first describe our empirical strategy. Second, we introduce the findings. Third, we discuss a number of robustness checks that we conducted. Finally, we explore some of the mechanisms that may account for the findings.

\subsection{Empirical Strategy}

\subsubsection{Overview}

Observing a correlation between state industrialized firms and residential segregation between Muslims and non-Muslims in their proximity does not necessarily imply a causal relationship because the locations of those firms are likely correlated with other characteristics of neighborhoods, both timeinvariant and time-variant, that could be also driving segregation. We address this problem as follows. First, we construct a panel dataset of 
locations that are observed in both 1848 and 1868. This allows us to exploit the change in industrialization at a given location between 1848 and 1868, while controlling for time-invariant characteristics of locations that may be correlated with both industrialization and segregation. Second, in order to mitigate the possibility of the differential evolution of segregation across locations even in the absence of changes in industrialization, our set of controls attempt to capture some of the neighborhood-specific changes during that period that may have impacted segregation.

In what follows, we first describe how we construct the panel dataset of locations. Second, we introduce our measure of local segregation. Third, we present our empirical specification. Finally, we provide descriptive statistics on all the variables that are included in the analysis.

\subsubsection{Creating a Panel Dataset of Locations}

We do not observe the same set of streets in each of 1848 and 1868. Hence, in order to compare the two years, we instead match locations (longitude and latitude). Since the number of possible locations is infinite, we define the universe of locations as the union of the sets of streets in 1848 and 1868. Then, within this universe, a location $j$ is matched between the two years, and is thus included in our panel sample, if we observe at least one household residing in its local neighborhood $S$ in both 1848 and 1868, where $S$ is defined to be a circle with a radius of 300 or 500 meters around that location. ${ }^{16}$ Furthermore, since segregation of a given religious group at a certain location is meaningless if there are no households of that group residing at the location, we further restrict our sample for examining the segregation of Muslims (non-Muslims) to locations where we observe at least one Muslim (non-Muslim) household in the local neighborhood of

\footnotetext{
${ }^{16}$ Notice that the number of locations in the panel dataset is increasing in the radius of the local neighborhood that we employ.
} 
location $j$ in both years. ${ }^{17}$ The sample restrictions result in a final sample of 918 and 921 locations for the segregation of Muslim households for the 300meters and the 500-meters radii respectively. The corresponding sample sizes for the segregation of non-Muslim households are 505 and 747 . Notice that the panel sample of locations with at least one Muslim household includes (almost) all households in the 1848 and 1868 census samples, ${ }^{18}$ but that the sample of locations with at least one non-Muslim household is limited to Cairo's mixed-religion locations. ${ }^{19}$

\subsubsection{Measuring Local Segregation}

We introduce a measure of local residential segregation between Muslims and non-Muslims. Inspired by Reardon and O'Sullivan (2004), we suggest using a segregation index that captures at each location $j$ the spatial egocentric isolation of a household of a given religious group $r(=$ Muslim or non-Muslim) from members of the other group:

$$
\text { Isolation }_{r j}=\text { PopShare }_{r j}=\frac{\sum_{q \in S} \text { Pop }_{r q}}{\sum_{q \in S} \text { Pop }_{q}}
$$

where PopShare Po is the population share of religious group $r$ in the local neighborhood $S$ of location $j$. The variables $P o p_{r q}$ and $P o p_{q}$ are the number of households of religious group $r$ and the total number of households respectively, measured in each street $q$ within the neighborhood

\footnotetext{
${ }^{17}$ If there are no Muslim (non-Muslim) households at a given location, our measure of local segregation will be equal to zero (i.e. no isolation), which is misleading. See the discussion of our measure of local segregation in the next sub-section.

${ }^{18}$ There are only 4 (1) locations without any Muslim households in their local neighborhoods in the 300 (500) meters samples, and are thus dropped from our panel sample.

${ }^{19}$ We exclude households that are located at exactly location $j$ from the definition of $S$. This is because for almost all locations, we observe households at the exact location $j$ in only one year but not the other. So in order to ensure consistency across the two years, we chose to compute all the variables in our analysis using households who live in the local neighborhood of each location, but not at the location itself. Technically, this exclusion modifies $S$ to include only households that lie within a radius that is greater than 5 meters but that is smaller than 300 or 500 meters. A radius $<300$ meters is highly sensitive to small changes in the local neighborhood of each household.
} 
$S$ around location $j$. Specifically, the isolation of Muslim (non-Muslim) households at each location is calculated by the proportion of Muslim (nonMuslim) households in the local neighborhood of each location. Intuitively, the index measures how likely it is for a household at a certain location to interact with members of her own religious group within her local neighborhood.

We calculate the index separately for Muslim and non-Muslim households. The index is symmetric between the two groups since the proportion of non-Muslims at any location is the complement of that of Muslims. Its value ranges from zero to one. A value close to zero for Muslims' (nonMuslims') isolation indicates that a Muslim (non-Muslim) household residing in that location mostly interacts with non-Muslim (Muslim) households (i.e. less inter-group isolation), whereas a value close to one for Muslims' (non-Muslims') isolation indicates that the location is almost entirely populated by Muslim (non-Muslim) households (i.e. more inter-group isolation).

\subsubsection{Empirical Specification}

In this setup, we define our dependent variable as the change in the intergroup isolation index for Muslim and non-Muslim households in the local neighborhood of location $j$. Our main regressor, the change in state industrialization between 1848 and 1868, is defined to capture the change at the extensive margin because of the difficulty of measuring the intensity of industrialization. There are four types of locations in our panel sample: (1) locations that had no large state firms in their close proximity in 1848 but witnessed the opening of at least one large state firm between 1848 and 1868, (2) locations that had at least one large state firm in 1848 but witnessed the closure of all those firms by 1868, (3) locations that had at least one large state firm in both 1848 and 1868, and (4) locations that had no large state firms in either 1848 or 1868. We think of types (1) and 
(2) as the "treated" locations, which witnessed changes in the instance of state industrialization, and of types (3) and (4) as the "control" locations that did not witness changes in the instance of industrialization.

The four types of locations are mapped in Figure 2. As in Figure 1, panels (A) and (B) plot in 1848 and 1868 respectively (mean coordinates of) streets that had in their proximity no large state firms and those that had at least one state firm. Panel (C) shows the change in the instance of state industrialization between the two years using our panel dataset of locations with at least one Muslim household within a radius of 300 meters that are observed in both years (918 locations). The comparison reveals that locations of type (1) (red in panel (C)) are those that were close to the opening of Cairo railway station (15 locations), whereas locations of type (2) (green) are those that were close to the closures of al-Khurunfish and al-Sayyida Zaynab textile firms (113 locations). Notice that we are not able to examine the impact of openings/closures of all other large state firms in Table 1, because their opening/closure did not generate in their close proximity a change in the instance of industrialization.

We then estimate the following OLS regression separately for the isolation of Muslim and non-Muslim households:

$$
\begin{aligned}
\Delta \text { Isolation }_{j}= & \beta_{0}+\beta_{1} \text { TextilesClosure }_{j}+\beta_{2} \text { RailwaysOpening }_{j} \\
& + \text { Trend }_{j} \Gamma+u_{j}
\end{aligned}
$$

where $\Delta$ Isolation $_{j}$ is the change between 1848 and 1868 in the egocentric isolation index measured in the local neighborhood of location $j$. The variable TextilesClosure is an indicator variable that takes the value of one if all textiles state firms within a 500-meters radius from the location closed down between 1848 and 1868 (type 2 locations). RailwaysOpening is an indicator variable that takes the value of one if Cairo railway station that opened in 1856 lies within a 500-meters radius from the location (type 


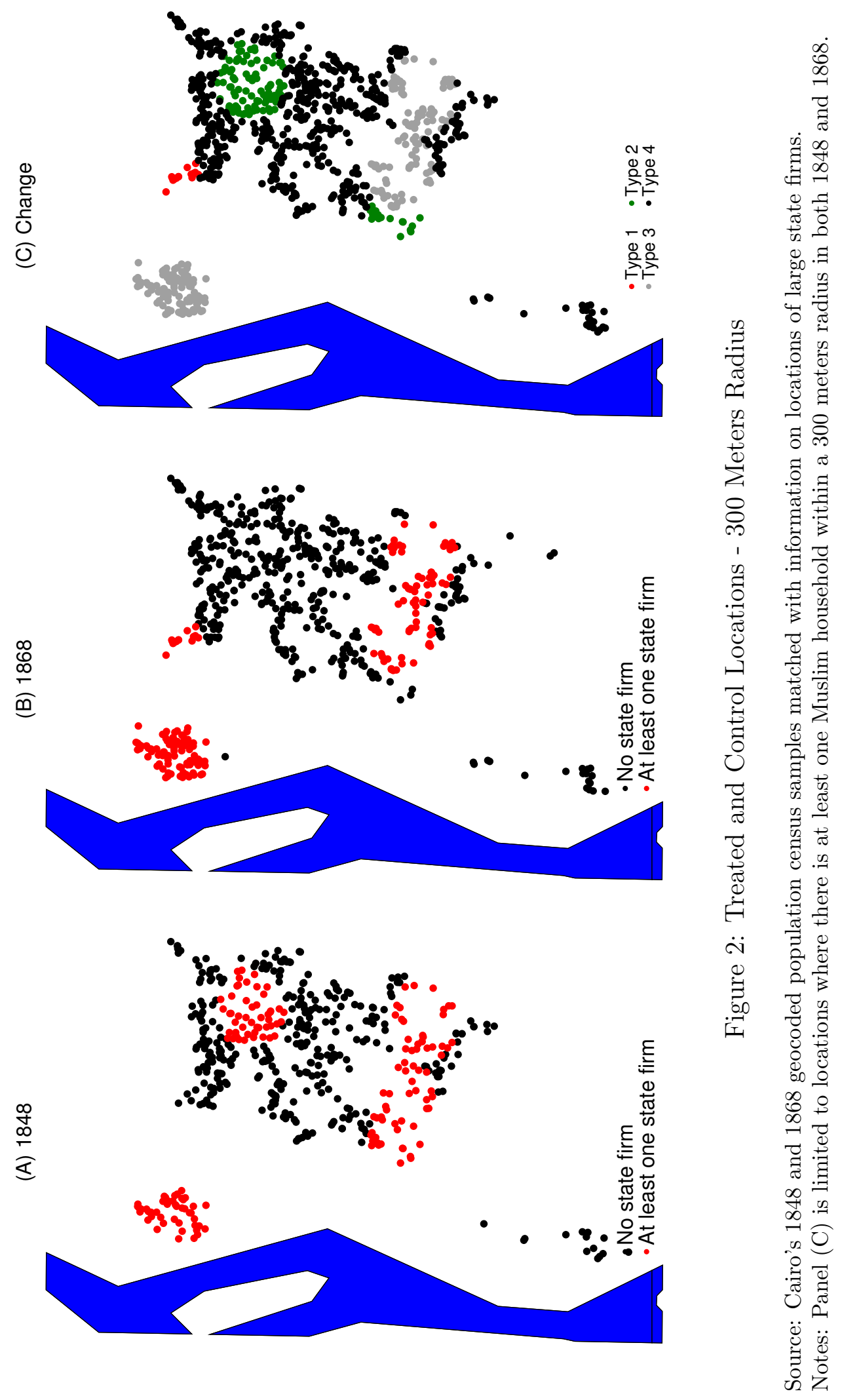


1 locations). The "control group" in this specification consists of locations of types (3) and (4) (grey and black in panel (C)) that did not witness changes in the instance of industrialization between 1848 and 1868. The error term, $u_{j}$, is assumed to be clustered at the quarter level according the 1848 census administrative division.

The vector Trend $_{j}$ includes a set of control variables that allow for the possibility that inter-group isolation may have evolved differentially across locations in 1848-1868 even in the absence of changes in industrialization. It includes three sets of variables. The first set of variables consists of time-invariant geographic variables which are: (1) distance to the Nile, (2) distance to the city center (average longitude and latitude), (3) distance to the Citadel (where the viceroy resided), (4) an indicator variable that takes the value of one if a location is in Bulaq suburb, and (5) an indicator variable that takes the value of one if a location is in Old Cairo suburb. The second set of variables consists of two (initial) demographic characteristics of locations in 1848 which are: (6) the value of the isolation index in 1848, and (7) the total number of households in $1848 .{ }^{20}$ The third set of variables control for two other public projects that were carried out in 1848-1868 which are: (8) distance to al-Ismailiya canal that was constructed in 18641866 (Raymond, 1993, p. 309), and (9) distance to al-Azbakiya garden (opened in 1837, but renovated between 1848 and 1868).

The impact of changes in the instance of state industrialization on intergroup isolation is captured by the coefficients $\beta_{1}$ and $\beta_{2}$.

\subsubsection{Discussion of Identification Assumption}

Since we exploit the change in industrialization between 1848 and 1868, the identification assumption here is that, conditional on controls, the evo-

\footnotetext{
${ }^{20}$ Controlling for the initial value of the isolation index in equation (2) is similar to estimating the equation using the level of isolation in 1868 as the dependent variable.
} 
lution of inter-group isolation between 1848 and 1868 would have been the same across treated and control locations in the absence of changes in the instance of state industrialization. The threat to identification comes from the potential endogeneity of the choice of locations that witnessed the opening of Cairo railway station in 1856 (type 1 locations) and the closures of two large state textiles firms in 1848-1868 (type 2 locations). ${ }^{21}$ While we are unable to completely rule out the potential endogeneity of openings and closures of firms, we are relatively confident that our specification addresses (what we believe to be) the most important threats to the identification assumption. In particular, we discuss below three sources of endogeneity: (a) reverse causality, (b) unobserved location-specific privatedriven changes in 1848-1868 that are correlated with changes in both industrialization and inter-group isolation, and (c) unobserved location-specific state-driven changes that took place between 1848 and $1868 .^{22}$

Reverse Causality The first concern that we have is that the state may have decided to open or close industrial firms in certain locations in 18481868 in response to changes in the religious composition, or inter-group isolation, of neighborhoods. This could be either due to a direct policy of targeting segregation, or an indirect policy, where openings and closures respond to (for example) shocks to the skill composition of the local populations, that are associated with changes in the religious composition of neighborhoods. However, there is no historical evidence that the choice of openings and closures of state firms was decided based on the evolution of

\footnotetext{
${ }^{21}$ Because we exploit the change in the instance of industrialization between 1848 and 1868, and not the level of industrialization in each of 1848 and 1868, our identification comes from the exogeneity of type 1 and type 2 locations only, conditional on controls, which is a weaker assumption than the exogeneity of locations of all large state firms that are listed in Table 1.

${ }^{22}$ Notice that city-level changes between 1848 and 1868 that are not location-specific are absorbed in the constant term $\beta_{0}$ in equation (2). These include, for example, changes in social norms on segregation and aggregate changes in income.
} 
the religious (or skill) composition of neighborhoods in 1848-1868. ${ }^{23}$ Instead, the choice of locations was likely based on technical factors. Cairo railway station was opened in the northwestern edge of the city which is closer to Alexandria, since the first railways line that was constructed connected the two cities (Sami, 1928, vol (3.1), p. 42). Looking at Table 1, we can see that as the state decided to close down most of its textiles firms after 1848, it decided to keep only 2 out of 6 firms in 1868, both located in Bulaq. This is likely because Bulaq was the most favorable location (from a technical viewpoint) for operating a textiles firm due to its proximity to Bulaq Nile port that presumably facilitated the importation of raw cotton and linen from the Nile Delta and the exportation of manufactured goods to consumer markets. ${ }^{24}$

Unobserved Private-Driven Changes Even if reverse causality is not a major concern, our specification may still be invalid if changes in state industrial firms and inter-group isolation were both correlated with the evolution of unobserved location-specific characteristics. Although we cannot rule out this concern, we argue that it is unlikely. First, historical evidence indicates that there were no (major) shocks to the demand side of the labor market in manufacturing, transportation, trade, and services, apart from state industrialized firms. Private firms in manufacturing and transportation sectors did not "industrialize" throughout the nineteenth century, in the sense that they (a) remained of a small size and (b) were

\footnotetext{
${ }^{23}$ Also, we are not aware that the local population of certain neighborhoods resisted the openings and/or closures of state firms to the extent of actually pushing the state to open and/or close a certain firm. This may reflect that the state did not assign a significant weight to the preferences of the local populations when making its opening/closure decisions.

${ }^{24}$ Sami (1928, vol. (3.1), p. 20) mentions an administrative order by which the state decided to shut down textiles state firms in the Nile Valley due to their remoteness from the Delta, where raw cotton was grown.
} 
not mechanized. ${ }^{25}$ Also, there is no indication of a major shock to private traders, providers of services, and professionals, except perhaps, the cotton boom in 1861-1865. However, although the cotton boom that quadrupled exports of raw cotton from the Nile Delta to Europe may have indirectly increased trade in Cairo, this likely affected the whole city, and was not location-specific. ${ }^{26}$ Second, the supply side of the labor market remained quite stable during the period. Although modern (European-style) public schools were introduced to Egypt during the first half of the nineteenth century (before 1848), modern schools, both public and private, served a tiny percentage of the population until the end of the century. Third, as in other cities in the Middle East, the vast majority of local amenities in nineteenth-century Cairo were privately provided. Yet, we were not able to identify (major) changes in the provision of local private amenities during the period including hospitals, bathhouses, drinking fountains, Sufi charity organizations, and markets. Fourth, to the best of our knowledge, the providers of religious services (mosques, churches, and synagogues) remained quite stable in $1848-1868 .^{27}$ Finally, there were no major private housing projects during the period (housing was mostly privately provided). Overall, this implies that, to the best of our knowledge, there were no (major) location-specific changes that took place in Cairo in 1848-1868 (and that are correlated with changes in industrialization and segregation), except for openings and closures of state industrial firms. Furthermore, even

\footnotetext{
${ }^{25}$ For example, textiles manufacturing outside state firms was practiced in small artisanal workshops that used manual spinning and weaving methods, whereas the private transportation sector consisted of drivers of animal-drawn vehicles and crews of sailing ships in the Nile.

${ }^{26}$ Relatedly, modern private banks were introduced to Cairo between 1848 and 1868 , but we only observe 3 individuals working in banks in 1868, suggesting that they likely served a tiny share of the population. Also, it is not obvious why banking would be correlated with both state industrialization or segregation.

${ }^{27}$ One exception here is the Citadel mosque which was opened in 1857 and is controlled for by our control variables. The partial destruction of Qaysun mosque (along with 700 houses) occurred after 1868 (in 1872-1873) (Raymond, 1993, pp. 303, 313).
} 
if there were other changes that were not reported by the contemporary literature, we think that our set of controls capture some of these potential changes by allowing for differential evolution of inter-group isolation across locations based on their distance to the city center, distance to the Nile, distance to Citadel, and population and inter-group isolation in 1848.

Other Unobserved State-Driven Changes Raymond (1993, p. 304) states that "After years marked by exciting changes, the reigns of Muhammad Ali's successors, Abbas I (1848-1854) and Sai'd (1854-1863) did not witness any grand achievement" (translation ours). There were only minor projects that took place between 1848 and 1863 including the construction of new streets between the Citadel and al-Azbakiya Garden in 1845-1863 and the establishment of military barracks in Qasr al-Nil in 1848-1863. However, it was Ismail (1863-1879), who initiated an ambitious modernization project of Cairo that is illustrated in Figure 3. This included the construction of al-Ismailiya Canal in 1864-1866 that provided water to the Suez Canal project, the provision of gas lighting in streets in 1865 (the firm was located in Bulaq), and the provision of clean water in 1867 (the project was closer to Old Cairo suburb in the southwest but remained limited to a tiny population as of 1891). ${ }^{28}$ We argue that our set of controls likely captures the most important location-specific public projects that took place in Cairo during that period: (a) we control for distances to al-Ismailiya canal, al-Azbakiya garden, and the Citadel, (b) we control for indicator variables for Bulaq and Old Cairo suburbs, where many state projects were located, and (c) distance to the Nile controls for Qasr al-Nil barracks. Notably, the construction of Cairo Downtown neighborhood in the west, which is Ismail's most famous project, occurred after $1868{ }^{29}$

\footnotetext{
${ }^{28}$ The construction of the Suez Canal in 1859-1869, that was opened in 1869, recruited workers from rural Egypt and thus likely had a little effect on Cairo.

${ }^{29}$ The western expansion of Cairo was formalized in a law in 1868 . However, only 13 percent of the expansion comprised residential structures in 1874 implying that it
} 


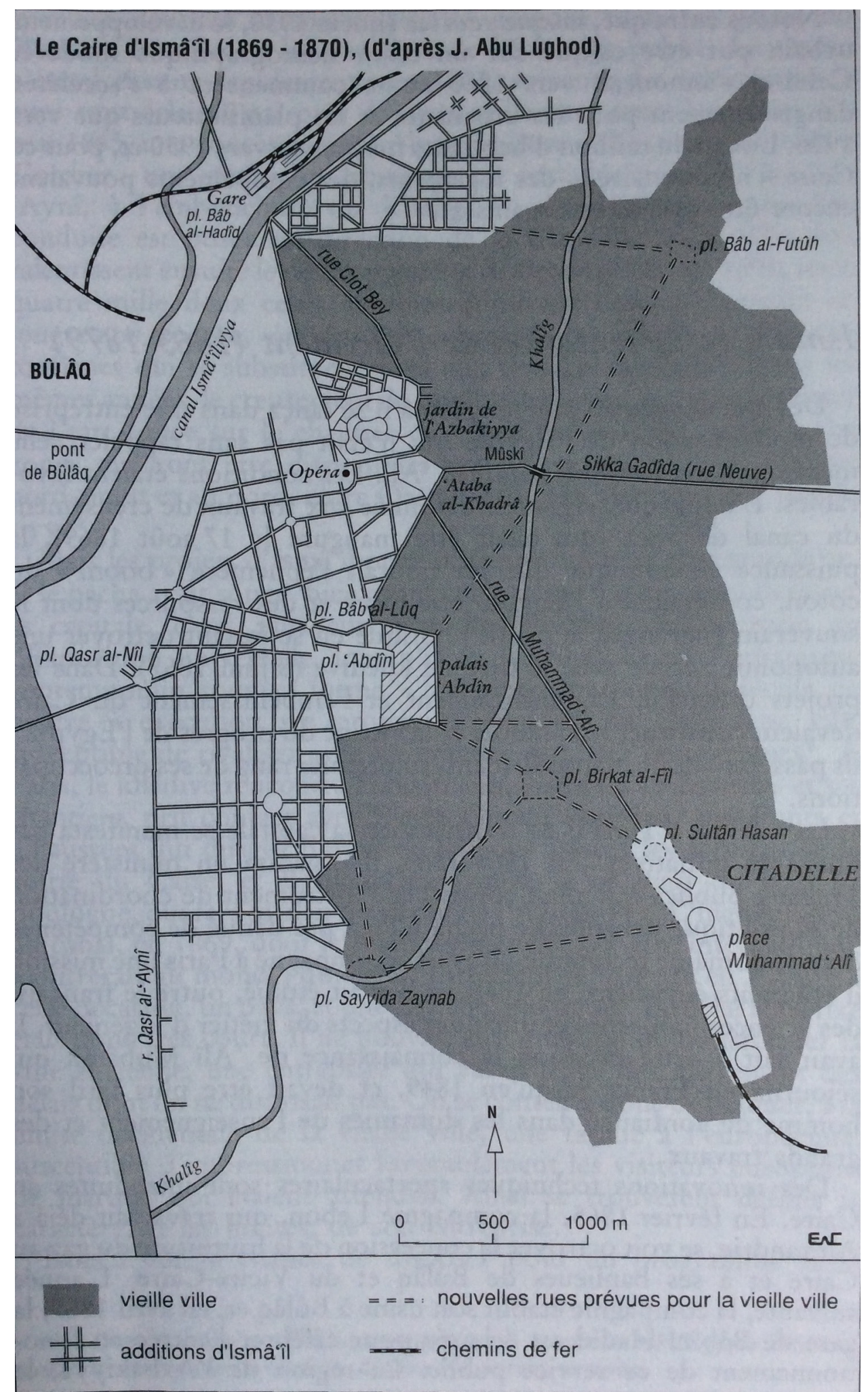

Figure 3: Ismail's Expansion of Western Cairo in 1869-1870

Source: Raymond (1993, p. 307). 


\subsubsection{Descriptive Statistics}

Table 3 introduces the summary statistics of the main variables in the empirical analysis using the 300-meters radius in constructing the panel sample. Consistent with the city-level segregation findings, the cross-location average isolation index for each of Muslims and non-Muslims changed little between 1848 and 1868. The typical Muslim household has 91-92 percent Muslims in her local neighborhood, while the average non-Muslim household is surrounded by $12-14$ percent non-Muslims. With respect to state industrialization, while 24-32 percent of locations in 1848 had at least one large textiles state firm within 500 meters, the percentage dropped to 1416 percent in 1868, as many firms closed down. Military firms were more stable though with the numbers being 17-19 and 15-16 percent in 1848 and 1868 respectively. Similarly, paper and printing firms were quite stable affecting 3-4 and 6-8 percent of all locations in 1848 and 1868 respectively. Only 2-3 percent of locations in 1868 were close to the railway station, whereas 11-14 percent of locations were close to the other transportation and communications firms (steam ships and telegraph stations).

\subsection{Results}

We now move on to the central findings of the article. Table 4 shows the estimation results of equation (2) which examines whether the change in inter-group isolation in a given location between 1848 and 1868 is altered by changes in the instance of state industrialization in proximity to that location. Panel (4a) indicates that Muslim (non-Muslim) households residing at a location that witnessed in its proximity the closure of all textiles firms

was still mostly uninhabited then (Raymond, 1993, pp. 310-312). This is confirmed by comparing the western expansion in Figure 3 to the 1868 population census in Figure 1 which indicates that the western area was barely inhabited in 1868. Among Ismail's other post-1868 projects are the construction of Cairo Opera House in 1869, the construction of Qasr al-Nil bridge in 1869, and the renovation of al-Azbakiya garden in 1872 . 
Table 3: Summary Statistics - 300-Meters Radius

\begin{tabular}{|c|c|c|c|c|c|c|}
\hline & \multicolumn{3}{|c|}{ "Locations with at Least One Muslim Household } & \multicolumn{3}{|c|}{ Locations with at Least One Non-Muslim Household } \\
\hline & 1848 & 1868 & Change & 1848 & 1868 & Change \\
\hline Isolation index & $0.92(0.16)$ & $0.91(0.17)$ & $-0.00(0.05)$ & $0.14(0.19)$ & $0.12(0.18)$ & $-0.00(0.07)$ \\
\hline Number of Muslim households & $126.54(53.78)$ & $179.64(91.34)$ & $53.30(64.06)$ & $134.14(59.09)$ & $191.99(96.18)$ & $56.02(75.23)$ \\
\hline Number of non-Muslim households & $11.51(20.48)$ & $14.93(26.90)$ & $5.11(10.58)$ & $19.11(23.49)$ & $19.96(29.45)$ & $5.11(10.58)$ \\
\hline \multicolumn{7}{|l|}{ State Industrialization - Cross-sectional: } \\
\hline$=1$ if a textile state firm in $500 \mathrm{~m}$ radius & $0.24(0.43)$ & $0.14(0.35)$ & - & $0.32(0.47)$ & $0.16(0.37)$ & - \\
\hline$=1$ if a military state firm in $500 \mathrm{~m}$ radius & $0.19(0.39)$ & $0.16(0.37)$ & - & $0.17(0.37)$ & $0.15(0.36)$ & - \\
\hline$=1$ if railways station in $500 \mathrm{~m}$ radius & - & $0.02(0.15)$ & - & - & $0.03(0.17)$ & - \\
\hline$=1$ if other transportation state firm in $500 \mathrm{~m}$ radius & - & $0.11(0.31)$ & - & - & $0.14(0.35)$ & - \\
\hline$=1$ if paper and printing state firm in $500 \mathrm{~m}$ radius & $0.03(0.17)$ & $0.06(0.24)$ & - & $0.04(0.20)$ & $0.08(0.27)$ & - \\
\hline \multicolumn{7}{|l|}{ State Industrialization - Panel: } \\
\hline$=1$ if all textile state firms closed in $500 \mathrm{~m}$ radius & - & - & $0.12(0.33)$ & - & - & $0.15(0.36)$ \\
\hline$=1$ if railways station opened in $500 \mathrm{~m}$ radius & - & - & $0.02(0.13)$ & - & - & $0.03(0.16)$ \\
\hline \multicolumn{7}{|l|}{ Controls: } \\
\hline$=1$ if located in Bulaq suburb & $0.09(0.29)$ & $0.14(0.35)$ & $0.12(0.32)$ & $0.14(0.35)$ & $0.16(0.37)$ & $0.16(0.37)$ \\
\hline$=1$ if located in Old Cairo suburb & $0.02(0.15)$ & $0.03(0.16)$ & $0.03(0.16)$ & $0.03(0.18)$ & $0.03(0.18)$ & $0.04(0.20)$ \\
\hline Distance to Nile & $2.39(0.91)$ & $2.30(1.00)$ & $2.36(0.95)$ & $2.16(0.90)$ & $2.22(1.02)$ & $2.11(0.96)$ \\
\hline Distance to city center & $1.41(0.82)$ & $1.53(0.84)$ & $1.47(0.82)$ & $1.41(0.89)$ & $1.49(0.85)$ & $1.44(0.92)$ \\
\hline Distance to the citadel & $2.28(1.11)$ & $2.43(1.21)$ & $2.34(1.17)$ & $2.55(1.10)$ & $2.57(1.17)$ & $2.63(1.13)$ \\
\hline Distance to Azbakiyaa garden & $1.61(0.92)$ & $1.68(0.90)$ & $1.64(0.90)$ & $1.47(0.99)$ & $1.55(0.89)$ & $1.47(0.99)$ \\
\hline Distance to the canal (1868 only) & $1.92(0.94)$ & $1.86(0.98)$ & $1.89(0.96)$ & $1.74(0.93)$ & $1.73(0.93)$ & $1.71(0.95)$ \\
\hline Number of households in 1848 & $138.04(54.67)$ & $135.29(54.35)$ & $137.09(53.73)$ & $153.25(56.70)$ & $144.02(53.70)$ & $152.79(56.95)$ \\
\hline Observations & 495 & 628 & 918 & 298 & 470 & 505 \\
\hline Locations (Type 1) & - & - & 15 & - & - & 14 \\
\hline Locations (Type 2) & - & - & 113 & - & - & 76 \\
\hline Locations (Type 3 ) & - & - & 208 & - & - & 99 \\
\hline Locations (Type 4 ) & - & - & 582 & - & - & 316 \\
\hline
\end{tabular}

Source: The " 1848 " and "1868" columns are based on streets that are observed in each of 1848 and 1868 respectively, whereas the "Change" column is from the panel sample of locations. The first three columns use the sample restricted to locations with at least one Muslim household, whereas the last three columns use the sample restricted to location with at least one non-Muslim household.

Notes: Means reported. Standard deviations are in parentheses. Isolation index in the first three columns is computed for Muslim households while in the last three columns is for non-Muslim households. See text for definitions of type 1 , type 2 , type 3 , and type 4 locations. 
between 1848 and 1868 experienced a greater decrease (increase) in their inter-group isolation compared to their co-religionists in locations that did not witness changes in industrialization (the control group). In terms of magnitude, the closure of all textiles firms is correlated with a differential decrease (increase) of 2-5 (3-9) percentage points in the level of inter-group isolation among Muslim (non-Muslim) households. This is a large magnitude if we consider that the average change in isolation in 1848-1868 across all locations is zero (see Table 3). In a similar vein, the opening of the railway station had an even greater effect on inter-group isolation. Whereas Muslim households who lived close to the station witnessed a greater increase in their isolation by 11-16 percentage points compared to the control group, non-Muslims experienced a greater decrease in isolation by $9-15$ percentage points compared to the control group. ${ }^{30}$

We then explore if the effects of industrialization on isolation are reflected in group-specific population movements. Specifically, we examine if changes in the instance of industrialization triggered in their close proximity differential changes in (a) number of Muslim households and/or (b) number of non-Muslim households, relative to locations in the control group. Conceptually, holding the initial number of Muslim and non-Muslim households in 1848 constant across locations, the change in Muslims' isolation index between 1848 and 1868 is positively (negatively) correlated with the change in the number of Muslim (non-Muslim) households, and the opposite holds for the isolation of non-Muslims. We thus re-estimate equation (2) using the change in number of Muslim households and the change in number of non-Muslim households as our dependent variables. We esti-

\footnotetext{
${ }^{30}$ While we admit that the number of locations "treated" by the railway station is small (15 locations), there are a few arguments that make us relatively confident in our results: (1) the results are consistent across type 1 and 2 locations, (2) these 15 locations contain roughly $2-3 \%$ of Cairo's population, and (3) as we discuss in the next section, we conducted a robustness check where we limited our control locations to those that lie within 1 kilometer from the railways station (hence treated locations in that regression are 15 out of 185 , i.e. $8 \%$ ), and we still obtain the same results (Table C.5).
} 
Table 4: Industrialization and Segregation: Panel Results

(a) Change in Isolation

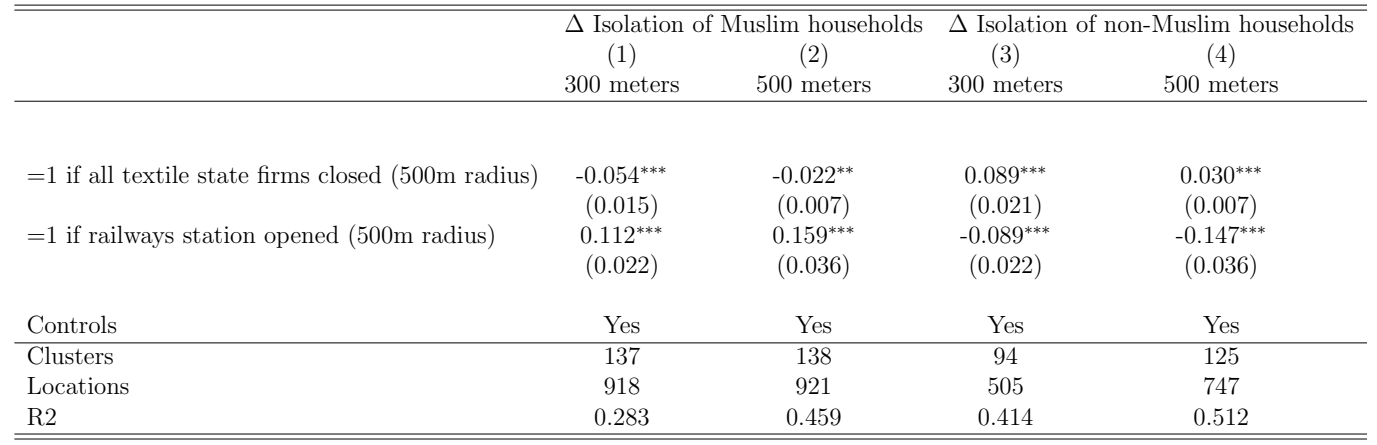

(b) Population Changes - Locations with at Least One Muslim Household

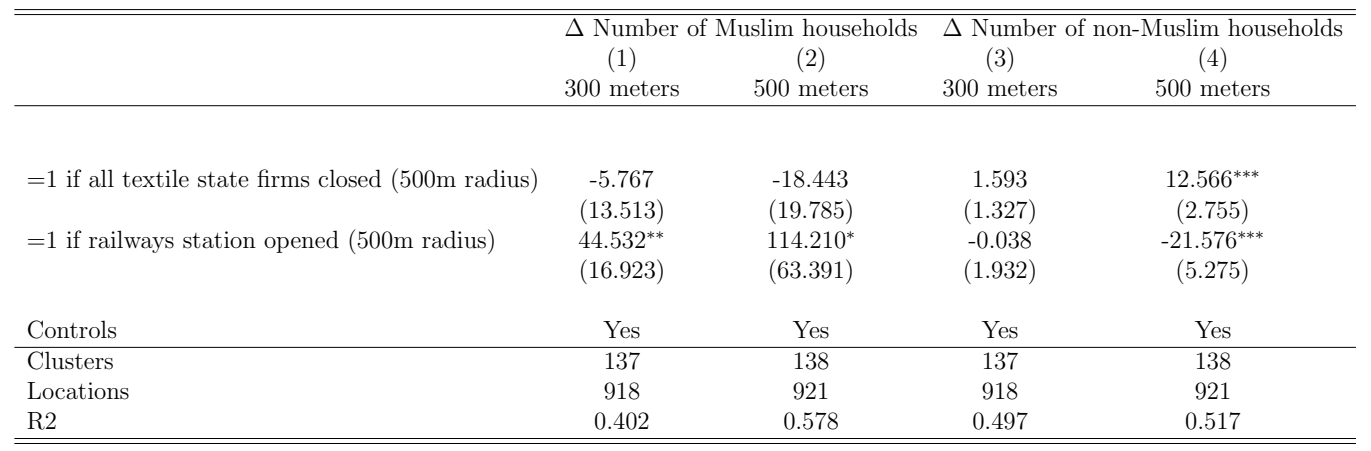

(c) Population Changes - Locations with at Least One Non-Muslim Household

\begin{tabular}{|c|c|c|c|c|}
\hline & \multicolumn{2}{|c|}{$\begin{array}{l}\Delta \text { Number of Muslim households } \\
\begin{array}{l}(1) \\
300 \text { meters }\end{array} \\
\text { (2) } \\
\text { (200 meters }\end{array}$} & \multicolumn{2}{|c|}{$\begin{array}{l}\Delta \text { Number of non-Muslim households } \\
\begin{array}{l}(3) \\
300 \text { meters }\end{array} \\
300 \text { meters } \\
\end{array}$} \\
\hline$=1$ if all textile state firms closed ( $500 \mathrm{~m}$ radius) & $\begin{array}{c}-36.597^{* *} \\
(14.505)\end{array}$ & $\begin{array}{l}-31.398^{*} \\
(17.525)\end{array}$ & $\begin{array}{l}2.858 \\
(2.170)\end{array}$ & $\begin{array}{c}14.033^{* * *} \\
(2.763)\end{array}$ \\
\hline$=1$ if railways station opened $(500 \mathrm{~m}$ radius $)$ & $\begin{array}{c}2.176 \\
(19.738)\end{array}$ & $\begin{array}{c}35.573 \\
(53.201)\end{array}$ & $\begin{array}{l}-2.066 \\
(2.340)\end{array}$ & $\begin{array}{c}-24.701^{* * *} \\
(5.188)\end{array}$ \\
\hline Controls & Yes & Yes & Yes & Yes \\
\hline Clusters & 94 & 125 & 94 & 125 \\
\hline Locations & 505 & 747 & 505 & 747 \\
\hline $\mathrm{R} 2$ & 0.631 & 0.687 & 0.495 & 0.527 \\
\hline
\end{tabular}

Source: Cairo's panel sample of locations that are observed in both 1848 and 1868 and defined using the 300 and 500 meters radii. Those are based on the 1848 and 1868 geocoded population census samples of Cairo aggregated to the household level and matched with information on locations of large state firms and other controls.

Notes: $* p<0.1, * * p<0.05, * * * p<0.01$. Standard errors clustered at the quarter level defined according to the administrative division of the 1848 census are in parentheses. 
mate separate sets of regressions for (a) locations with at least one Muslim household where the isolation of Muslims is defined, and (b) locations with at least one non-Muslim household where the isolation of non-Muslims is defined.

The results of this exercise are shown in panels (4b) and (4c). The findings reveal that the effects of the closures of textiles firms on isolation are attributable to a differential decrease in the number of Muslim households nearby the closures and by a lesser magnitude to a differential increase in the number of non-Muslim households, although the results are not always statistically significant. Similarly, the effect of the opening of the railway station on isolation is primarily driven by a differential increase in the number of Muslim households nearby the railway station and secondarily by a differential decrease in the number of non-Muslim households.

To summarize, the central findings of the article are as follows. Changes in state industrialization between 1848 and 1868 appear to have affected the isolation of Muslim and non-Muslim households in their close proximity as they led to differential changes in the sizes of the Muslim and non-Muslim populations. Whereas the opening of Cairo railway station differentially increased Muslims' isolation, the closures of textiles firms differentially decreased it. And the opposite effects hold for the isolation of non-Muslims, which differentially decreased close to the railway station and increased close to the closures of the textiles firms. In the next sub-section, we conduct a number of robustness checks before we examine some of the mechanisms that may be driving these findings in more depth.

\subsection{Robustness Checks}

There are a number of concerns about the findings in Table 4 that we attempt to address in this sub-section. We relegate the results of this subsection to section $(\mathrm{C})$ of the online appendix in order to save space. 
State Industrialization or State Jobs? An alternative interpretation of the findings is that changes in the instance of state industrialization simply reflect (location-specific) changes in number of state jobs between 1848 and 1868, but not state industrialization per se. Indeed, apart from state industrialized firms, the state recruited workers in other governmental entities such as (civil) bureaucracy, military, police, judiciary, and public construction works, and changes in employment in these entities in 1848-1868 might be correlated with the evolution of inter-group isolation. Fortunately, the 1848 and 1868 census samples record the workplace of all workers in any state job, and not only those in state manufacturing, transportation, and communications firms. We are thus able to include the change in number of workers in state "non-industrialized" entities as a control variable. The results, reported in Table C.1, reveal that changes in state industrialization retain their effects. Therefore, the evolution of inter-group isolation is specifically attributable to changes in state industrialization, and not to state jobs more generally.

Alternative Segregation Measure Although our inter-group isolation index captures the likelihood of a household at a given location to interact with households from her own group within the local neighborhood of her location, it does not take into account how households are spatially distributed within that local neighborhood. For example, it could be that a non-Muslim household is surrounded by a high share of Muslim households (i.e. less isolated), however Muslim and non-Muslim households rarely interact because they live on different streets within the neighborhood. Table C.2 employs as alternative dependent variables changes in the number and proportion of "mixed-religion streets," that is, streets with both Muslim and non-Muslims households. Since Muslims constitute the vast majority of the population, we expect mixed-religion streets to reflect the isolation 
index of Muslims rather than non-Muslims. We find that relative to locations in the control group, the opening of the railways station differentially decreased both the number and share of mixed-religion streets in its proximity, which is consistent with our finding that the station differentially increased Muslims' isolation. However, the effect of the textiles closures is statistically insignificant.

Is Control Group a Valid Counterfactual? Locations in the control group may be different from treated locations with respect to unobservable characteristics. The control group includes (a) locations that had at least one state industrial firm in their proximity in both 1848 and 1868 (type 3) and (b) locations that did not have any state firms in their proximity in either year (type 4). One concern is that type 3 locations witnessed multiple openings and closures of firms and hence may not constitute a proper control group. To address this concern, we re-estimated equation (2) using locations of type (4) as the control group and including an indicator variable for locations of type (3) as an additional regressor. The results are shown in Table C.3 and are unchanged from the main findings, which suggests that type (3) locations are not driving our findings.

We also changed the control group by re-estimating the regressions for each type of state industrial firms while restricting the sample to locations that lie within a 1-kilometer radius from the opening or closure of state firms. The results are in Tables C.4 and C.5 and are similar to the main findings. Alternatively, we control for a polynomial in longitude and latitude (instead of our set of controls). The results are shown in Table C.6 and are also similar to the main findings.

Heterogeneity Within Non-Muslims? Since non-Muslims include Copts, non-Coptic Christians, and Jews, who may have heterogeneous responses 
to state firms, we re-estimated equation (2) with Copts and Muslims only, as Copts were the largest non-Muslim group. The results in Table C.7 are similar to the main findings.

Correcting for Serial Correlation We assumed an arbitrary type of serial correlation based on clustering within the same quarter that is defined according to the 1848-census administrative boundaries. We thus re-estimated the regressions while correcting for more general forms of spatial correlation between locations. The results are in Tables C.8 and C.9 and are similar to the main findings.

\subsection{Understanding the Mechanisms}

\subsubsection{Industrialization, Population Movements, and Segregation}

By definition, residential segregation between religious groups is a function of the spatial distribution of each religious group, and hence group-specific population movements that are triggered by changes in the instance of state industrialization, may alter residential segregation. To explore the population movements that could be driving our findings, we estimate, as a first step, the impact of changes in the instance of state industrialization between 1848 and 1868 on changes in number of households of certain characteristics. To save space, we show the results on the mechanisms for the panel sample that uses the 300-meters radius in defining local neighborhoods (the results for the 500-meters sample are similar). In particular, we estimate the following equation:

$$
\Delta y_{j l}=\tilde{\theta}_{0 l}+\tilde{\theta}_{1 l} \text { TextilesClosure }_{j}+\tilde{\theta}_{2 l} \text { RailwaysOpening }_{j}+\text { Trend }_{j} \tilde{\Theta}_{l}+\tilde{\epsilon}_{j l}
$$


where $\Delta y_{j l}$ is the change at location $j$ in the number of households of a given characteristic $l$. These include seven characteristics which are defined at the level of the household head: (1) the number of workers in state industrialized firms, (2) the number of rural immigrants (born outside Cairo), (3) the number of foreigners, (4) the number of unskilled workers, (5) the number of artisans, (6) the number of white-collar workers, and (7) the number of households living in low-status dwellings (courtyards, huts, rooms, mills, stables, bathhouses). Trend $_{j}$ is defined as in equation (2).

Then as a second step, we explore the correlation between these population changes and the change in the isolation index:

$$
\Delta_{\text {solation }_{j}}=\theta_{0}+\sum_{l=1}^{7} \theta_{l} \Delta y_{j l}+\text { Trend }_{j} \Theta+\epsilon_{j}
$$

As before, we estimate separate regressions for locations with at least one Muslim household and those with at least one non-Muslim household.

The results of the first step of this exercise (equation (3)) for locations with at least one Muslim household are shown in Table 5. Panel (5a) indicates that, relative to locations in the control group, the closures of textiles firms generated in their proximity a greater decrease in the number of households headed by unskilled workers and rural immigrants (although the latter effect is not statistically significant). It also generated a greater increase in the number of foreigner households. Breaking down these population changes by religion in panels $(5 b)$ and $(5 c)$ reveals that the effects on unskilled workers and rural immigrants are attributable to Muslims, but that the effect on foreigners is due to non-Muslims.

With respect to railways, panel (5a) reveals that the opening of Cairo railway station triggered greater increases in the numbers of households headed by state firm workers, rural immigrants, foreigners, and unskilled workers, and in the number of households residing in low-status dwellings, 
with the effects on low-status dwellings households, rural immigrants, and unskilled workers being of the largest magnitudes. According to panels (5b) and (5c), the effects are primarily due to Muslims.

The results for the restricted sample of locations with at least one nonMuslim household are shown in Table 6 and are qualitatively similar to those in Table 5 albeit with a few exceptions. With respect to the closures of textiles firms, the positive effect on the change in the number of foreigners now loses its statistical significance whereas their effect on the change in the number of immigrants gains statistical significance. Also, there is now a positive effect on the change in the number of state firm workers and a negative effect on the change in the number of white-collar workers. With respect to the railway station, the effect on the change in the number of foreigners is now statistically insignificant, but there is a negative and significant effect on the change in the number of white-collar workers.

To summarize these results, we focus on the effects that are qualitatively robust across both samples for two reasons, (a) the effect must be large enough to be pronounced for the whole city, i.e. in the sample with at least one Muslim household and (b) the effect must be observed in the restricted sample of locations with at least one non-Muslim household because it is in these locations that Muslims and non-Muslims likely interact. Basically, compared to the control group, the opening of Cairo railway station in 1856 attracted in its proximity greater net inflows of households residing in lowstatus dwellings, rural immigrants, unskilled workers, state firm workers, and foreigners; all these groups were mostly Muslims. Perhaps in a similar vein, the closures of textiles firms generated greater net outflows of rural immigrants and unskilled workers, both groups were mostly Muslims, and a greater net inflow of foreigners, who were mostly non-Muslims. In the next sub-section, we attempt to interpret these findings.

The results of the second step of the exercise (equation (4)), the corre- 
Table 5: Industrialization and Population Changes (300-Meters Radius) Locations with at Least One Muslim Household

(a) Population Changes

\begin{tabular}{|c|c|c|c|c|c|c|c|}
\hline & $\begin{array}{c}(1) \\
\text { State firm workers }\end{array}$ & $\begin{array}{c}(2) \\
\text { Immigrants }\end{array}$ & $\begin{array}{c}\Delta \text { Number } \\
(3) \\
\text { Foreigners }\end{array}$ & $\begin{array}{c}\text { of househol } \\
(4) \\
\text { Unskilled }\end{array}$ & $\begin{array}{c}\text { ds } \\
\text { Artisans } \\
\end{array}$ & $\begin{array}{c}(6) \\
\text { White-Collar }\end{array}$ & $\begin{array}{c}(7) \\
\text { Low-S D }\end{array}$ \\
\hline$=1$ if all textile state firms closed ( $500 \mathrm{~m}$ radius) & $\begin{array}{c}1.224 \\
(0.801)\end{array}$ & $\begin{array}{c}-5.279 \\
(4.311)\end{array}$ & $\begin{array}{l}6.544^{* *} \\
(2.724)\end{array}$ & $\begin{array}{c}-9.600^{* *} \\
(3.673)\end{array}$ & $\begin{array}{l}-1.015 \\
(3.398)\end{array}$ & $\begin{array}{c}2.678 \\
(4.900)\end{array}$ & $\begin{array}{c}0.500 \\
(2.948)\end{array}$ \\
\hline$=1$ if railways station opened (500m radius) & $\begin{array}{c}8.499^{* * *} \\
(1.727)\end{array}$ & $\begin{array}{c}29.109^{* * *} \\
(6.790)\end{array}$ & $\begin{array}{c}10.393^{* * *} \\
(2.195)\end{array}$ & $\begin{array}{l}15.463^{* *} \\
(4.820)\end{array}$ & $\begin{array}{c}7.990 \\
(5.720)\end{array}$ & $\begin{array}{c}8.264 \\
(5.180)\end{array}$ & $\begin{array}{c}42.710^{* * *} \\
(6.512)\end{array}$ \\
\hline Controls & Yes & Yes & Yes & Yes & Yes & Yes & Yes \\
\hline Clusters & 137 & 137 & 137 & 137 & 137 & 137 & 137 \\
\hline Locations & 918 & 918 & 918 & 918 & 918 & 918 & 918 \\
\hline $\mathrm{R} 2$ & 0.605 & 0.430 & 0.272 & 0.317 & 0.426 & 0.324 & 0.544 \\
\hline
\end{tabular}

(b) Muslim Population Changes

\begin{tabular}{|c|c|c|c|c|c|c|c|}
\hline & $\begin{array}{c}(1) \\
\text { State firm workers }\end{array}$ & \begin{tabular}{c}
\multicolumn{1}{c}{$\Delta$} \\
Immigrants
\end{tabular} & $\begin{array}{c}\text { Number of } 1 \\
(3) \\
\text { Foreigners }\end{array}$ & $\begin{array}{c}\text { uslim hous } \\
\text { (4) } \\
\text { Unskilled }\end{array}$ & $\begin{array}{l}\text { holds } \\
\text { (5) } \\
\text { Artisans }\end{array}$ & $\begin{array}{c}(6) \\
\text { White-Collar }\end{array}$ & $\begin{array}{c}(7) \\
\text { Low-S D }\end{array}$ \\
\hline$=1$ if all textile state firms closed ( $500 \mathrm{~m}$ radius) & $\begin{array}{c}0.986 \\
(0.729)\end{array}$ & $\begin{array}{c}-5.932 \\
(4.295)\end{array}$ & $\begin{array}{c}-1.336 \\
(1.670)\end{array}$ & $\begin{array}{c}-8.918^{* *} \\
(3.149)\end{array}$ & $\begin{array}{c}-5.230 \\
(3.741)\end{array}$ & $\begin{array}{c}3.770 \\
(4.609)\end{array}$ & $\begin{array}{c}1.130 \\
(2.902)\end{array}$ \\
\hline$=1$ if railways station opened (500m radius) & $\begin{array}{c}6.697^{* * *} \\
(1.317)\end{array}$ & $\begin{array}{c}25.196^{* * *} \\
(6.178)\end{array}$ & $\begin{array}{c}8.376^{* * *} \\
(1.511)\end{array}$ & $\begin{array}{c}18.541^{* * *} \\
(4.319)\end{array}$ & $\begin{array}{c}8.843 \\
(5.981)\end{array}$ & $\begin{array}{c}8.743 \\
(5.310)\end{array}$ & $\begin{array}{c}40.744^{* * *} \\
(6.221)\end{array}$ \\
\hline Controls & Yes & Yes & Yes & Yes & Yes & Yes & Yes \\
\hline Clusters & 137 & 137 & 137 & 137 & 137 & 137 & 137 \\
\hline Locations & 918 & 918 & 918 & 918 & 918 & 918 & 918 \\
\hline $\mathrm{R} 2$ & 0.596 & 0.419 & 0.173 & 0.320 & 0.468 & 0.399 & 0.542 \\
\hline
\end{tabular}

(c) Non-Muslim Population Changes

\begin{tabular}{|c|c|c|c|c|c|c|c|}
\hline & $\begin{array}{l}\text { (1) } \\
\text { State firm workers }\end{array}$ & \begin{tabular}{c}
\multicolumn{1}{c}{$\Delta \mathrm{N}_{1}$} \\
$(2)$ \\
Immigrants
\end{tabular} & $\begin{array}{c}\text { mber of non } \\
\quad(3) \\
\text { Foreigners }\end{array}$ & $\begin{array}{c}\text { Muslim ho } \\
\text { (4) } \\
\text { Unskilled }\end{array}$ & $\begin{array}{l}\text { iseholds } \\
\text { (5) } \\
\text { Artisans }\end{array}$ & $\begin{array}{c}(6) \\
\text { White-Collar }\end{array}$ & $\begin{array}{c}(7) \\
\text { Low-S D }\end{array}$ \\
\hline$=1$ if all textile state firms closed ( $500 \mathrm{~m}$ radius) & $\begin{array}{c}0.238 \\
(0.160)\end{array}$ & $\begin{array}{l}0.652^{*} \\
(0.348)\end{array}$ & $\begin{array}{c}7.880^{* * *} \\
(2.121)\end{array}$ & $\begin{array}{l}-0.682 \\
(0.779)\end{array}$ & $\begin{array}{c}4.216^{* * *} \\
(0.892)\end{array}$ & $\begin{array}{r}-1.092^{*} \\
(0.642)\end{array}$ & $\begin{array}{c}-0.630^{* * *} \\
(0.170)\end{array}$ \\
\hline$=1$ if railways station opened ( $500 \mathrm{~m}$ radius) & $\begin{array}{l}1.801^{* *} \\
(0.807)\end{array}$ & $\begin{array}{l}3.913^{* * *} \\
(1.084)\end{array}$ & $\begin{array}{l}2.017 \\
(2.396)\end{array}$ & $\begin{array}{l}-3.079^{* *} \\
(1.134)\end{array}$ & $\begin{array}{l}-0.853 \\
(1.073)\end{array}$ & $\begin{array}{l}-0.479 \\
(1.514)\end{array}$ & $\begin{array}{l}1.966^{* * *} \\
(0.384)\end{array}$ \\
\hline Controls & Yes & Yes & Yes & Yes & Yes & Yes & Yes \\
\hline Clusters & 137 & 137 & 137 & 137 & 137 & 137 & 137 \\
\hline Locations & 918 & 918 & 918 & 918 & 918 & 918 & 918 \\
\hline $\mathrm{R} 2$ & 0.377 & 0.349 & 0.296 & 0.401 & 0.509 & 0.520 & 0.394 \\
\hline
\end{tabular}

Source: Cairo's panel sample of locations that are observed in both 1848 and 1868 and defined using the 300-meters radius. Locations are restricted to those with at least one Muslim household. Those are based on the 1848 and 1868 geocoded population census samples of Cairo aggregated to the household level and matched with information on

Notes: $* p<0.1, * * p<0.05, * * * p<0.01$. Standard errors clustered at the quarter level according to the 1848 -census administrative boundaries are in parentheses. 
Table 6: Industrialization and Population Changes (300-Meters Radius) Locations with at Least One Non-Muslim Household

(a) Population Changes

\begin{tabular}{|c|c|c|c|c|c|c|c|}
\hline & $\begin{array}{c}(1) \\
\text { State firm workers }\end{array}$ & $\begin{array}{c}(2) \\
\text { Immigrants }\end{array}$ & $\begin{array}{c}\Delta \text { Number } \\
(3) \\
\text { Foreigners }\end{array}$ & $\begin{array}{c}\text { of househol } \\
(4) \\
\text { Unskilled }\end{array}$ & $\begin{array}{c}\text { ls } \\
\text { Artisans } \\
\text { Ans }\end{array}$ & $\begin{array}{c}(6) \\
\text { White-Collar }\end{array}$ & $\begin{array}{c}(7) \\
\text { Low-S D }\end{array}$ \\
\hline$=1$ if all textile state firms closed (500m radius) & $\begin{array}{l}1.654^{*} \\
(0.991)\end{array}$ & $\begin{array}{c}-17.446^{* *} \\
(7.333)\end{array}$ & $\begin{array}{c}2.937 \\
(3.356)\end{array}$ & $\begin{array}{c}-13.968^{* *} \\
(4.922)\end{array}$ & $\begin{array}{l}-4.056 \\
(4.231)\end{array}$ & $\begin{array}{c}-11.435^{* *} \\
(3.676)\end{array}$ & $\begin{array}{c}4.768 \\
(3.017)\end{array}$ \\
\hline$=1$ if railways station opened ( $500 \mathrm{~m}$ radius) & $\begin{array}{l}6.545^{* *} \\
(2.316)\end{array}$ & $\begin{array}{c}23.515^{* *} \\
(8.162)\end{array}$ & $\begin{array}{l}4.390 \\
(2.987)\end{array}$ & $\begin{array}{c}12.300^{* *} \\
(6.034)\end{array}$ & $\begin{array}{l}-0.148 \\
(6.919)\end{array}$ & $\begin{array}{c}-18.117^{* *} \\
(6.205)\end{array}$ & $\begin{array}{c}45.369^{* * *} \\
(8.503)\end{array}$ \\
\hline Controls & Yes & Yes & Yes & Yes & Yes & Yes & Yes \\
\hline Clusters & 94 & 94 & 94 & 94 & 94 & 94 & 94 \\
\hline Locations & 505 & 505 & 505 & 505 & 505 & 505 & 505 \\
\hline R2 & 0.644 & 0.569 & 0.326 & 0.515 & 0.590 & 0.572 & 0.701 \\
\hline
\end{tabular}

(b) Muslim Population Changes

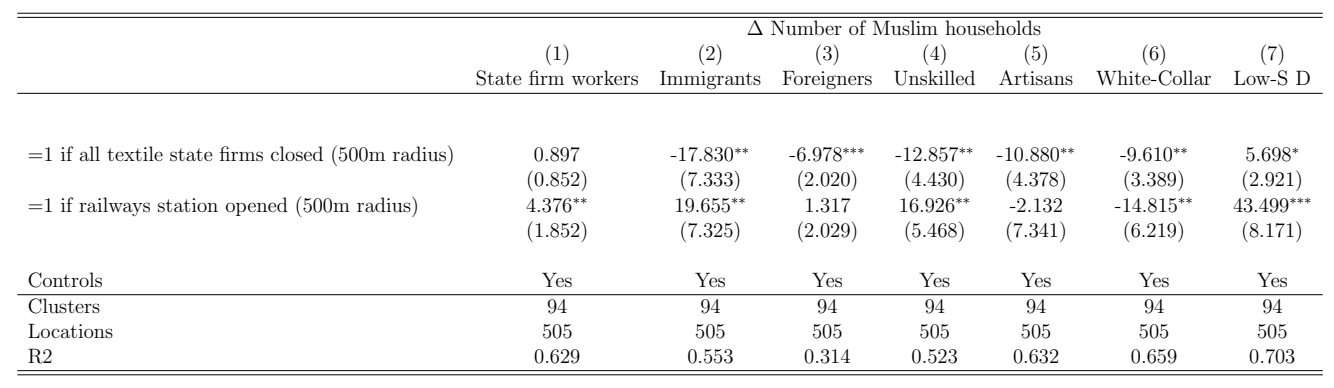

(c) Non-Muslim Population Changes

\begin{tabular}{|c|c|c|c|c|c|c|c|}
\hline & $\begin{array}{c}(1) \\
\text { State firm workers }\end{array}$ & \begin{tabular}{c}
\multicolumn{1}{c}{$\Delta \mathrm{Nl}_{1}$} \\
Immigrants
\end{tabular} & $\begin{array}{c}\text { mber of non } \\
\quad(3) \\
\text { Foreigners }\end{array}$ & $\begin{array}{c}\text {-Muslim hor } \\
\text { (4) } \\
\text { Unskilled }\end{array}$ & $\begin{array}{l}\text { iseholds } \\
(5) \\
\text { Artisans } \\
\end{array}$ & $\begin{array}{c}(6) \\
\text { White-Collar }\end{array}$ & $\begin{array}{c}(7) \\
\text { Low-S D }\end{array}$ \\
\hline$=1$ if all textile state firms closed ( $500 \mathrm{~m}$ radius) & $\begin{array}{c}0.757^{* *} \\
(0.337)\end{array}$ & $\begin{array}{c}0.383 \\
(0.542)\end{array}$ & $\begin{array}{l}9.915^{* *} \\
(3.381)\end{array}$ & $\begin{array}{l}-1.110 \\
(1.030)\end{array}$ & $\begin{array}{c}6.824^{* * *} \\
(1.332)\end{array}$ & $\begin{array}{c}-1.824^{* *} \\
(0.858)\end{array}$ & $\begin{array}{c}-0.930^{* * *} \\
(0.220)\end{array}$ \\
\hline$=1$ if railways station opened ( $500 \mathrm{~m}$ radius) & $\begin{array}{l}2.169^{*} \\
(1.125)\end{array}$ & $\begin{array}{l}3.860^{* *} \\
(1.360)\end{array}$ & $\begin{array}{l}3.072 \\
(2.866)\end{array}$ & $\begin{array}{l}-4.626^{* *} \\
(1.476)\end{array}$ & $\begin{array}{l}1.983 \\
(1.899)\end{array}$ & $\begin{array}{l}-3.302^{* *} \\
(1.380)\end{array}$ & $\begin{array}{l}1.871^{* * *} \\
(0.414)\end{array}$ \\
\hline Controls & Yes & Yes & Yes & Yes & Yes & Yes & Yes \\
\hline Clusters & 94 & 94 & 94 & 94 & 94 & 94 & 94 \\
\hline Locations & 505 & 505 & 505 & 505 & 505 & 505 & 505 \\
\hline $\mathrm{R} 2$ & 0.500 & 0.467 & 0.323 & 0.491 & 0.623 & 0.560 & 0.461 \\
\hline
\end{tabular}

Source: Cairo's panel sample of locations that are observed in both 1848 and 1868 and defined using the 300-meters radius. Locations are restricted to those with at least one non-Muslim household. Those are based on the 1848 and 1868 geocoded population census samples of Cairo aggregated to the household level and matched with information on locations of large state firms and other controls.

Notes: $* p<0.1, * * p<0.05, * * * p<0.01$. Standard errors clustered at the quarter level according to the 1848-census administrative boundaries are in parentheses. 
lation between population movements and isolation, are in Table 7. Panel (7a) reveals that a greater increase in the number of households headed by rural immigrants, unskilled workers, or inhabitants of low-status dwellings differentially augments the isolation of Muslim households. By contrast, a greater increase in the number of foreigner households differentially reduces Muslims' isolation. panel (7b) shows that the opposite correlations hold with respect to the isolation of non-Muslim households. These results likely stem from the fact that Muslims were over-represented among rural immigrants, unskilled workers, and inhabitants of low-status dwellings, and were under-represented among foreigners (see Table A.1 in the online appendix). Consequently, a greater increase in the population size of one of the first three groups differentially aggravates (mitigates) the isolation of Muslims (non-Muslims), whereas a greater increase in the foreigner population has the opposite effects. Interestingly, changes in the numbers of households headed by state firm workers, artisans, or white-collar workers are not correlated with changes in isolation.

\subsubsection{Industrialization and the Housing Market}

If industrialization triggered population movements that altered segregation, a natural question is if and how the housing market responded. Unfortunately, it is not possible to examine this question in full because we do not observe housing prices, but the census samples provide two pieces of information that may offer some useful clues. The first piece of information is the "type of dwelling" that allows us to identify (a) "low-status dwellings," such as courtyards, huts, rooms, stables, mills, bathhouses, which we could think of as "urban slums" and (b) "multiple-household dwellings," such as tenement houses, which we could think of as "middle-class dwellings." The second piece of information is the "type of property rights on dwellings" that includes ownership (almost all private), waqf or religious endowment, 
Table 7: Correlations between Population Changes and Isolation

(a) Correlations between Population Changes and Isolation of Muslims (300-Meters Radius) - Locations with at Least One Muslim Household

\begin{tabular}{|c|c|c|c|c|}
\hline & $\Delta$ Isole & tion of $\mathrm{M}$ & slim hou & eholds \\
\hline & $(1)$ & $(2)$ & $(3)$ & $(4)$ \\
\hline Change in number of state firm workers & $\begin{array}{c}0.000 \\
(0.000)\end{array}$ & & & \\
\hline Change in number of immigrants & & $\begin{array}{c}0.001^{* * *} \\
(0.000)\end{array}$ & & \\
\hline Change in number of foreigners & & $\begin{array}{c}-0.001^{* * *} \\
(0.000)\end{array}$ & & \\
\hline Change in number of unskilled workers & & & $\begin{array}{l}0.001^{* *} \\
(0.000)\end{array}$ & \\
\hline Change in number of artisans & & & $\begin{array}{l}-0.000 \\
(0.000)\end{array}$ & \\
\hline Change in number of white-collar workers & & & $\begin{array}{c}0.000 \\
(0.000)\end{array}$ & \\
\hline Change in number of households in low-status dwellings & & & & $\begin{array}{l}0.001^{* *} \\
(0.000)\end{array}$ \\
\hline Controls & Yes & Yes & Yes & Yes \\
\hline Clusters & 137 & 137 & 137 & 137 \\
\hline Locations & 918 & 918 & 918 & 918 \\
\hline $\mathrm{R} 2$ & 0.120 & 0.213 & 0.187 & 0.155 \\
\hline
\end{tabular}

(b) Correlations between Population Changes and Isolation of Non-Muslims (300-Meters Radius) - Locations with at Least One Non-Muslim Household

$\Delta$ Isolation of non-Muslim households

$\begin{array}{llll}(1) & (2) & (3) & (4)\end{array}$

Change in number of state firm workers

$-0.000$

Change in number of immigrants

$(0.001)$

Change in number of foreigners

Change in number of unskilled workers

(0.001)

Change in number of artisans

Change in number of white-collar workers

\begin{tabular}{lcccc} 
Controls & Yes & Yes & Yes & Yes \\
\hline Clusters & 94 & 94 & 94 & 94 \\
Locations & 505 & 505 & 505 & 505 \\
R2 & 0.201 & 0.358 & 0.313 & 0.250 \\
\hline \hline
\end{tabular}

Source: Cairo's panel sample of locations that are observed in both 1848 and 1868 and defined using the 300-meters radius. Those are based on the 1848 and 1868 geocoded population census samples of Cairo aggregated to the household level and matched with information on locations of large state firms and other geographic information. Notes: $* p<0.1, * * p<0.05, * * * p<0.01$. Standard errors clustered at the quarter level according to the Notes: $* p<0.1, * * p<0.05, * * * p<0.01$
1848-census boundaries are in parentheses. 
and undefined property rights (likely, slums).

To examine the correlation between industrialization and the housing outcomes we use the same specification as in equation 3 with the following dependent variables (measured as the change between 1848 and 1868): (1) the total number of dwellings, (2) the number of low-status dwellings, (3) the number of multiple-household dwellings, (4) the number of dwellings of other types, (5) the number of owned dwellings, (6) the number of waqf dwellings, and (7) the number of dwellings with undefined property rights.

The results of this exercise are shown in Table 8. First, the closures of textiles firms are correlated with a greater decrease in the number of lowstatus dwellings and a greater increase in the number of multiple-household dwellings in their proximity, relative to locations in the control group. Second, compared to the control group, the opening of the railway station is correlated with a bigger rise in the total number of dwellings in its proximity, which is attributable to a greater increase in the number of lowstatus dwellings and in the number of dwellings with undefined property rights. We also observe a larger decline in the number of multiple-household dwellings around the railway station. We interpret these two sets of results as evidence that the housing market responded to state industrialization; a response that seems to be consistent with the population movements that we documented in the two previous subsections. As the closures of textiles firms generated greater net outflows of rural immigrants and unskilled workers, who likely resided in low-status dwellings, we observe a greater decrease in this "poor" type of dwellings following the closures of the firms and the flight of these population groups. Similarly, as the opening of the railway station attracted greater net inflows of rural immigrants and unskilled workers, we observe greater increases in low-status dwellings and dwellings with undefined property rights which perhaps marked the 
creation of an "urban slum" around the station. ${ }^{31}$

Table 8: Industrialization and the Housing Market (300-Meters Radius All Locations) - Dependent Variable is the Change in the Number of Dwellings in a Given Category

\begin{tabular}{|c|c|c|c|c|c|c|c|}
\hline & \multicolumn{4}{|c|}{$\begin{array}{l}\text { Dwelling Types } \\
\end{array}$} & \multicolumn{3}{|c|}{ Property Rights Types } \\
\hline & (1) & (2) & (3) & (4) & (5) & (6) & (7) \\
\hline & Total & Low-Status & Multiple-HH & Other & Owned & Waqf & Undefined \\
\hline$=1$ if all textile state firms closed (500m radius) & -10.059 & $-3.403^{* *}$ & $2.884^{* * *}$ & -9.539 & -7.019 & -2.646 & -0.394 \\
\hline & $(7.081)$ & $(1.300)$ & $(0.838)$ & $(5.965)$ & $(4.891)$ & $(1.796)$ & $(2.252)$ \\
\hline$=1$ if railways station opened (500m radius) & $27.638^{* * *}$ & $38.781^{* * *}$ & $-2.456^{* *}$ & -8.687 & 6.874 & 3.078 & $17.686^{* * *}$ \\
\hline & $(7.456)$ & $(3.885)$ & $(0.775)$ & $(7.012)$ & $(8.347)$ & $(1.974)$ & $(3.229)$ \\
\hline Controls & Yes & Yes & Yes & Yes & Yes & Yes & Yes \\
\hline Clusters & 137 & 137 & 137 & 137 & 137 & 137 & 137 \\
\hline Locations & 919 & 919 & 919 & 919 & 919 & 919 & 919 \\
\hline R2 & 0.374 & 0.671 & 0.307 & 0.232 & 0.405 & 0.217 & 0.391 \\
\hline
\end{tabular}

Source: Cairo's panel sample of locations that are observed in both 1848 and 1868 and defined using the 300-meters radius. Those are based on the 1848 and 1868 geocoded population census samples of Cairo aggregated to the household level and matched with information on locations of large state firms and other controls.

Notes: $* p<0.1, * * p<0.05, * * * p<0.01$. Standard errors clustered at the quarter level according to the 1848 -census boundaries are in parentheses.

\subsubsection{Interpreting the Mechanisms}

There are at least two mechanisms through which state industrial firms can induce group-specific population movements, and hence residential segregation: (1) They may affect the demand for labor either directly, by attracting people to work in the firm, or indirectly by crowding in, or crowding out, private jobs in their proximity. If commuting cost is sufficiently high such that people mostly live close to their workplace (which is likely the case in nineteenth-century Cairo where people walked to their workplace), state firms may alter the residential choice of workers in both state firms and the private sector. (2) Apart from the labor market mechanism, state firms may affect amenities (e.g., noise or pollution) in their proximity, thus inducing people to live close by, or rather away from, the firm. The two effects may differ by religious group because of inter-group differences in occupations and the weight they put on amenities when making their resi-

\footnotetext{
${ }^{31}$ At the city level, the share of ownerships decreased from 76 to 68 percent between 1848 and 1868, the share of waqf dwellings remained stable at 17-18 percent, but the share of dwellings with undefined property rights increased from 5 to 14 percent.
} 
dential choices. Furthermore, population movements that are triggered by changes in state industrialization may be enhanced or mitigated by an individual's taste for living close to her own religious group. While the results on population movements do not allow us to disentangle these mechanisms, they at least offer some clues. In particular, we argue that the findings are consistent with an indirect labor market mechanism.

Labor Market versus Amenities To begin with, it appears unlikely that the direct labor market mechanism is the primary driver of the results. The impact on the evolution of the number of state industrial firm workers is positive and statistically significant in only the case of the railway station, and even there its magnitude is modest compared to the impact of the station on other population movements such as inhabitants of lowstatus dwellings, rural immigrants, and unskilled workers. This implies that most industrialization-induced population movements were not by worker in state industrial firms.

The amenities mechanism is consistent with certain results but not others. Consistent with the amenities mechanism, we find that the closures of textiles firms attracted in their proximity a greater net inflow of nonMuslim foreigners, mostly Europeans, which may indeed reflect the negative effect on amenities that these firms had (when they were still open). ${ }^{32}$ However, we find that the opening of the railway station attracted a greater net inflow of Muslim foreigners, which is not consistent with the (likely) negative effects on amenities of the station. Also, we failed to observe neither an (positive) effect of the closures of textiles firms on attracting a greater net inflow of white-collar workers (who would likely assign a higher weight to amenities when making their residential choices), nor a (negative)

\footnotetext{
${ }^{32}$ There is suggestive evidence on the negative environmental effects of textiles firms. For example, there were complaints made by foreigners demanding the closure of alKhurunfish textiles firm (Al-Gritli, 1952, p. 64).
} 
effect of the railway station on triggering a greater "flight" of white-collar workers. Overall, this indicates that the amenities mechanism is inconsistent with many findings.

This leaves us with the indirect labor market mechanism on workers outside state industrial firms, as the most likely mechanism: (1) The railway station (textiles closures) generated greater net inflows (outflows) of rural immigrants and unskilled workers, who were not in their most part workers in state industrial firms, or in any state job, but in the private sector. (2) The effects on unskilled workers and rural immigrants are (in most cases) of the largest magnitudes compared to other population movements. We hence interpret our findings as follows. The opening of the railway station crowded in private-sector unskilled jobs in its proximity that attracted unskilled workers as well as poor and stranded rural immigrants who recently arrived into the city. Examples of these jobs are drivers of animal-drawn vehicles, water porters, porters, laborers, servants, and construction workers. Likewise, the closures of textiles firms crowded out private-sector unskilled jobs and thus pushed away unskilled workers and rural immigrants. Since Muslims were over-represented among both groups, the opening of the railways station (the closures of textiles firms) resulted in greater net inflows (outflows) of Muslims that were translated into a differentially higher (lower) isolation of Muslims and a differentially lower (higher) isolation of non-Muslims. ${ }^{33}$

Taste for Segregation Our findings are consistent with the hypothesis that labor market considerations were likely more important than taste for segregation in an individual's residential choice, especially among the

\footnotetext{
${ }^{33}$ The effects on foreigners could also be explained by an indirect labor market mechanism whereby the railways opening crowded in jobs for Muslim foreigners whereas the textiles closures attracted back non-Muslim foreigners whose jobs were perhaps crowded out by those firms.
} 
poor. In particular, notwithstanding the fact that the railways station was opened in a high non-Muslim concentration neighborhood (50 percent nonMuslim in 1848), it still attracted greater net inflows of Muslim unskilled workers and rural immigrants. This implies that even if these individuals had preferred to live in a purely Muslim neighborhood, their need to find a job probably outweighed their taste for segregation. A similar argument applies in the case of the textiles closures, which occurred in another high non-Muslim concentration neighborhood (20 percent in 1848), and generated greater net outflows of unskilled and rural immigrant Muslims, who likely chose to live in the proximity of textiles firms (when they were still open) despite the presence of non-Muslims.

\section{Conclusion}

This article documented the impact of industrialization on the residential segregation between religious groups using an early program of state industrialization in nineteenth-century Cairo. The program that lasted from 1816 to 1879 spanned several industries, most notably textiles, besides the construction of one of the first railways in the Middle East connecting Cairo and Alexandria. To examine this question, we employed a novel data source, individual-level census samples from 1848 and 1868 that contain the street address of each household along with a rich set of demographic and socioeconomic information. The data allow us to geo-locate each household at the street level; a fine geographic level that is quite unusual in studies of segregation, both historical and contemporary. We merge this data source with information on the locations of Cairo's large state firms.

We first documented that industrialization had little of an impact on the city-level segregation in Cairo, which was quite high to begin with. We then explored if changes in the instance of industrialization between 1848 and 
1868 affected local segregation. We found that the largest effect on segregation came from the opening of Cairo railway station in 1856 that differentially increased Muslims' isolation in its proximity, followed by the closures of two large textiles firms that differentially decreased it. We attribute these findings to an "indirect" labor market mechanism whereby state firms attract greater net inflows of rural immigrants and unskilled workers in order to possibly benefit from the private-sector unskilled jobs that are crowded in around the firm. Because Muslims were over-represented among these groups, industrialization was correlated with greater net inflows of Muslims that was translated into a differentially higher Muslims' isolation (equivalently, a differentially lower non-Muslims' isolation).

The findings open new areas for research. For one thing, one may wonder if the subsequent waves of industrialization in twentieth-century Egypt, whether on part of the state or the private sector, may have impacted segregation in Cairo and other Egyptian cities in the long run. For another, as with most historical case studies of this sort, a normal concern is to what degree one is able to generalize these findings beyond the historical context. While we think that there are certain aspects of this study that may be specific to Egypt including, for example, the historically high level of segregation and the long-standing socioeconomic advantage of the non-Muslim minority over the Muslim majority, we think that the main argument of the article, that industrialization may cause population movements because of a labor market mechanism, and that this may in turn impact local residential segregation is quite generalizable to other contexts with similar industrialization experiments. These include, first, small-scale industrialization, because in contrast to twentieth-century large-scale programs in China, Soviet Union, and Eastern Europe, Egypt's program employed a small share of the population, and hence, in terms of magnitude, it is perhaps more comparable to the (market-driven) first IR in Continental 
Europe and recent industrialization attempts in developing countries. Second, it is relevant to cases where industrialized firms are established within an existing city, without expanding the city surface area, at least in the short run. Third, and relatedly, it is perhaps relevant to urbanization and the formation of urban slums in developing countries.

\section{References}

Al-Gritli, A. (1952). tarikh al-sina'a fi misr fil nisf al-awwal min al-qarn al tasi' 'ashar (History of Industry in Egypt in the First Half of the Nineteenth Century). Cairo: Dar El-Ma'aref.

Al-Hitta, A. A. (1967). tarikh misr al-iqtisadi fil qarn al tasi' 'ashar (Economic History of Egypt in the Nineteenth Century). Cairo: Al-Masry Publishing.

Al-Maqrizi, T. (2002). al-mawa'iz wal i'tibar fi zhikr al-khitat wal athar (Sermons and Considerations in Examining Plans and Monuments), volume 4. Ayman Fouad Sayyid (Ed.) (London: Al-Furqan Islamic Heritage Foundation).

Ananat, E. O. (2011). The Wrong Side(s) of the Tracks: The Causal Effects of Racial Segregation on Urban Poverty and Inequality. American Economic Journal: Applied Economics, 3(2):34-66.

Ananat, E. O. and Washington, E. (2009). Segregation and Black Political Efficacy. Journal of Public Economics, 93(5-6):807-822.

Banzhaf, H. S. and Walsh, R. P. (2013). Segregation and Tiebout Sorting: The Link between Place-based Investments and Neighborhood Tipping. Journal of Urban Economics, 74:83-98. 
Bayer, P., Ferreira, F., and McMillan, R. (2007). A Unified Framework for Measuring Preferences for Schools and Neighborhoods. Journal of Political Economy, 115.

Bayer, P. and McMillan, R. (2012). Tiebout Sorting and Neighborhood Stratification. Journal of Public Economics, 96(11-12):1129-1143.

Boustan, L. P. (2011). Racial Residential Segregation in American Cities. In The Oxford Handbook of Urban Economics and Planning. Oxford: Oxford University Press.

Boustan, L. P. and Margo, R. A. (2009). Race, Segregation, and Postal Employment: New Evidence on Spatial Mismatch. Journal of Urban Economics, 65(1):1-10.

Card, D., Mas, A., and Rothstein, J. (2008). Tipping and the Dynamics of Segregation. The Quarterly Journal of Economics, 123(1):177-218.

Collins, W. J. and Margo, R. A. (2000). Residential segregation and socioeconomic outcomes: When did ghettos go bad? Economics Letters, $69(2): 239-243$.

Corvalan, A. and Vargas, M. (2015). Segregation and conflict: An empirical analysis. Journal of Development Economics, 116:212 - 222.

Cutler, D. M. and Glaeser, E. L. (1997). Are Ghettos Good or Bad? The Quarterly Journal of Economics, 112(3):827-872.

Cutler, D. M., Glaeser, E. L., and Vigdor, J. L. (1999). The Rise and Decline of the American Ghetto. Journal of Political Economy, 107.

DeBats, D. A. and Lethbridge, M. (2005). Gis and the City: NineteenthCentury Residential Patterns. Historical Geography, 33:78-98. 
Dennis, R. (1984 (1986)). English Industrial Cities of the Nineteenth Century A Social Geography. Cambridge: Cambridge University Press Studies in Historical Geography.

Dridi, A. (2014). Églises et Synagogues de Fustật-Le Caire à l'Epoque Mamelouke. Entre Destructions et Adaptations Spatiales. Hypothèses.

Dridi, A. (2015). Christians of Fustat in the First Three Centuries of Islam. The Making of a New Society. In A Cosmopolitan City. Muslims, Christians and Jews in Old Cairo. ed. T. Vorderstrasse and T. Treptow, Chicago: Oriental Institute Museum Publications.

Duncan, O. D. and Duncan, B. (1955). A Methodological Analysis of Segregation Indexes. American Sociological Review, 20(2).

Echenique, F. and Fryer, R. G. (2007). A Measure of Segregation Based on Social Interactions. The Quarterly Journal of Economics, 122(2):441485 .

Engels, F. (1993[1845]). The Condition of the Working Class in England. Oxford: Oxford University Press.

Fahmy, M. (1954). La Révolution de l'Industrie en Egypte et Ses Conséquences Sociales au 19e Siècle (1800-1850). Leiden: E. J. Brill.

Field, E., Levinson, M., Pande, R., and Visaria, S. (2008). Segregation, rent control, and riots: The economics of religious conflict in an indian city. The American Economic Review, 98(2):505-510.

Ghazaleh, P. (1999). Masters of the Trade: Crafts and Craftspeople in Cairo, 1750-1850. American University in Cairo Press, Cairo.

Gilliland, J. and Olson, S. (2010). Residential Segregation in the Industrializing City: A Closer Look. Urban Geography, 31:29-58. 
Gilliland, J., Olson, S., and Gauvreau, D. (2011). Did Segregation Increase as the City Expanded? Montreal 1881-1901. Social Science History, $35: 465-503$.

Greenberg, S. W. (1981). Industrial Location and Ethnic Residential Patterns in an Industrializing City. In Hershberg, T., editor, Philadelphia: Work, Space, Family and GroupExperience in the Nineteenth Century, page 204-232. New York: Oxford University Press.

Hellerstein, J. K., Neumark, D., and McInerney, M. (2008). Spatial Mismatch or Racial Mismatch? Journal of Urban Economics, 64(2):464-479.

Hershberg, T., Burstein, A. N., Ericksen, E. P., Greenberg, S., and Yancey, W. L. (1979). A Tale of Three Cities: Blacks and Immigrants in Philadelphia: 1850-1880, 1930 and 1970. The ANNALS of the American Academy of Political and Social Science, 441(1):55-81.

Johnston, R., Poulsen, M., and Forrest, J. (2011). Evaluating Changing Residential Segregation in Auckland, New Zealand, Using Spatial Statistic. Tijdschrift voor economische en sociale geografie, 102(1):1-23.

Jomard, M. (1829). Description de la ville et de la citadelle du Kaire. In Roderick Floud, J. H. and Johnson, P., editors, Description de l'Egypte. Paris: Imp. de C.L.F. Panckoucke.

Kain, J. F. (1968). Housing Segregation, Negro Employment, and Metropolitan Decentralization. The Quarterly Journal of Economics, $82(2): 175-197$.

Kain, J. F. (1992). The Spatial Mismatch Hypothesis: Three Decades Later. Housing Policy Debate, 3(2):371-460.

Marsot, A. L. A. (1984). Egypt in the Reign of Muhammad Ali. Cambridge: Cambridge University Press. 
Massey, D. S. (2016). Segregation and Perpetuation of Disadvantage. In The Oxford Handbook of the Social Science of Poverty. eds. David Brady, Linda M. Burton, James B Duke, Oxford: Oxford University Press.

Massey, D. S. and Denton, N. A. (1988). The Dimensions of Residential Segregation. Social Forces, 67(2):281-315.

Mehta, S. K. (1969). Patterns of Residence in Poona, India, by Caste and Religion: 1822-1965. Demography, 6.

Mele, A. (2013). Poisson Indices of Segregation. Regional Science and Urban Economics, 43(1):65 - 85.

Mubarak, A. (1887). al-khitat al-tawfiqiya al-jadida li misr al-qahira wa muduniha wa biladiha al-qadima wal shahira (The New Tewfiqi Plans for Egypt, Its Cities, and Its Old and Famous Villages). Cairo: Bulaq Printing House.

Owen, R. (2002). The Middle East in the World Economy 1800-1914. I. B. Tauris and Co Ltd, London.

Pamuk, S. (2006). Estimating Economic Growth in the Middle East since 1820. Journal of Economic History, 66:809-828.

Pancs, R. and Vriend, N. J. (2007). Schelling's Spatial Proximity Model of Segregation Revisited. Journal of Public Economics, 91(1-2):1-24.

Park, R. E. and Burgess, E. W. (1925). The City. Chicago: University of Chicago Press.

Pratt, E. (1911). Industrial Causes of Congestion of Population in New York City. New York: Columbia University Press.

Raymond, A. (1973). Artisans et Commerçants au Caire au XVIIIe Siècle. Damascus: Institut Français de Damas. 
Raymond, A. (1993). Le Caire. Paris: Fayard.

Reardon, S. F., Matthews, S. A., O'Sullivan, D., Lee, B. A., Firebaugh, G., Farrell, C. R., and Bischoff, K. (2008). The Geographic Scale of Metropolitan Racial Segregation. Demography, 45(3):489-514.

Reardon, S. F. and O'Sullivan, D. (2004). Measures of Spatial Segregation. Sociological Methodology, 34(1):121-162.

Royuela, V. and Vargas, M. (2010). Residential Segregation: A Literature Review. Universidad Diego Portales Working Paper.

Saleh, M. (2013). A Pre-Colonial Population Brought to Light: Digitization of the Nineteenth-Century Egyptian Censuses. Historical Methods: A Journal of Quantitative and Interdisciplinary History, 46:5-18.

Saleh, M. (2015). The Reluctant Transformation: State Industrialization, Religion, and Human Capital in Nineteenth-Century Egypt. The Journal of Economic History, 75:65-94.

Sami, A. (1928). taqwim al-neel (Chronicles of the Nile). Cairo: Dar AlKutub.

Schelling, T. C. (1971). Dynamic Models of Segregation. The Journal of Mathematical Sociology, 1(2):143-186.

Shaw-Taylor, L. and Wrigley, E. A. (2014). Occupational Structure and Population Change. In Roderick Floud, J. H. and Johnson, P., editors, The Cambridge Economic History of Modern Britain. Volume 1: 17001870. Cambridge: Cambridge University Press.

Östh, J., Clark, W. A. V., and Malmberg, B. (2015). Measuring the Scale of Segregation Using k-Nearest Neighbor Aggregates. Geographical Analysis, 47(1):34-49. 
Trounstine, J. (2016). Segregation and inequality in public goods. American Journal of Political Science, 60(3):709-725.

Uslaner, E. M. (2012). Segregation and Mistrust Diversity, Isolation, and Social Cohesion. Cambridge University Press, Cambridge.

Vithayathil, T. and Singh, G. (2012). Spaces of Discrimination: Residential Segregation in Indian Cities. Economic and Political Weekly, 47.

Ward, D. (1975). Victorian Cities: How Modern? Journal of Historical Geography, 1:135-151.

Ward, D. (1980). Environs and Neighbours in the "Two Nations": Residential Differentiation in Mid-Nineteenth Century Leeds. Journal of Historical Geography, 6:133-162.

Warner, S. B. (1968). The Private City: Philadelphia in Three Periods of Its Growth. Philadelphia, PA: University of Pennsylvania Press.

Wirth, L. (1928). The Ghetto. Chicago: University of Chicago Press.

Wong, D. W., Reibel, M., and Dawkins, C. J. (2007). Introduction-Segregation and Neighborhood Change: Where Are We after More Than a Half-Century of Formal Analysis? Urban Geography, 28(4):305311.

Zunz, O. (1982). The Changing Face of Inequality: Urbanization, Industrial Development, and Immigrants in Detroit, 1880-1920. Chicago: University of Chicago Press. 


\section{Appendix for Online Publication}

\section{Appendix A Data Appendix}

This section shows the descriptive statistics on certain socioeconomic variables for each religious group in 1848 and 1868 .

Table A.1: Characteristics of Cairo's Muslim and Non-Muslim Populations in 1848 and 1868

\begin{tabular}{lcccc}
\hline & \multicolumn{2}{c}{ Muslims } & \multicolumn{2}{c}{ Non-Muslims } \\
& $\mathbf{1 8 4 8}$ & $\mathbf{1 8 6 8}$ & $\mathbf{1 8 4 8}$ & $\mathbf{1 8 6 8}$ \\
\hline State firm workers & $10.5 \%$ & $3.5 \%$ & $6 \%$ & $3.5 \%$ \\
Rural immigrants & $27.25 \%$ & $11.35 \%$ & $8.71 \%$ & $5.56 \%$ \\
Foreigners & $7 \%$ & $5.5 \%$ & $25 \%$ & $25 \%$ \\
Unskilled workers & $45 \%$ & $39.5 \%$ & $17 \%$ & $17 \%$ \\
Artisans & $35 \%$ & $38 \%$ & $37 \%$ & $32 \%$ \\
White-collar workers & $20 \%$ & $22.5 \%$ & $46 \%$ & $51 \%$ \\
Residents in low-status dwellings & $15.15 \%$ & $14.6 \%$ & $3.19 \%$ & $0.91 \%$ \\
\hline
\end{tabular}




\section{Appendix B City-level Segregation}

\section{B.1 Creation of "Artificial Neighborhoods"}

In order to measure the city-level segregation consistently across 1848 and 1868, we construct "artificial neighborhoods" whose boundaries are constant in the two years. These were constructed using a grid of $20 * 20$ and $25^{*} 25$ cells that "discretize" the city space. We then match every household to a cell in the grid, where we only keep cells that are populated in both years.

To be specific, we use the following procedure in creating the neighborhoods:

1. Using the pooled sample of geocoded streets in both years, we compute:

$\Delta$ Latitude $=$ Max Latitude - Min Latitude

and:

$\Delta$ Longitude $=$ Max Longitude - Min Longitude

where Max (Min) Longitude (Latitude) refers to the maximum (minimum) longitude (latitude) observed in the sample.

2. In order to create the grid we divide the city space into equal cells:

Step Latitude $=\Delta \frac{\text { Latitude }}{k}$

and:

Step Longitude $=\Delta \frac{\text { Longitude }}{l}$.

where we chose neighborhoods to be squares with $k=l=20$ or $25 .^{34}$

3. The two previous steps allow us to create a point at the center of each cell at regular intervals. For $i=1,2, \ldots, k+1$ and $y=1,2, \ldots, l+1$

\footnotetext{
${ }^{34} \mathrm{As}$ an alternative, we test all possible combinations of $k$ and $l$ which are greater than 1 and smaller than 60 and we select the pair that maximizes the number of "populated" neighborhoods.
} 
we create all points $x^{i, y}$ with coordinates:

$$
\begin{gathered}
x_{\text {latitude }}^{i, y}=\text { Min Latitude }+(i-1) \times \text { Step Latitude } \\
x_{\text {longitude }}^{i, y}=\text { Min Longitude }+(y-1) \times \text { Step Longitude }
\end{gathered}
$$

4. We match every household to the closest point (i.e. cell or neighborhood) $x^{i, y}$.

5. We only keep cells (neighborhoods) such that:

a) The neighborhood must be populated in each year. In practice, we restricted neighborhoods to those with at least five households matched to the cell in each year.

b) There must be at least two different streets matched to the point in each year.

There are at least two caveats to this procedure though. First, since we impose regular intervals when creating the grid, we arbitrarily chose artificial neighborhoods to be of a particular shape. Second, as we restrict neighborhoods to those which were populated in both years, we are not able to examine the emergence of new neighborhoods.

\section{B.2 Spatial Dissimilarity and Isolation Indexes}

With artificial neighborhoods, it is possible to compute the "standard" isolation indexes consistently in both 1848 and 1868. We also compute "spatial" versions of the segregation indexes which we explain below.

We proceed in two steps. First, we count the numbers of Muslim, non-Muslim, and the total number of households in the local environment of each "artificial neighborhood." Basically, we draw a circle of radius $y$ 
(300 and 500 meters) around each neighborhood and define the local environment as all the "artificial neighborhoods" whose center lies within the circle. The total number of households in the local environment is then computed as the weighted sum of the number of households in all artificial neighborhoods within the circle:

$$
\operatorname{Pop}_{\tilde{T o t a l}}^{j, t}=\frac{1}{\Phi_{j, t}} \sum_{q=1}^{n} \operatorname{PopTotal}_{q, t} \times \phi(j, q)
$$

where PopTotal ${ }_{j, t}$ is the total number of households in the local environment of an "artificial neighborhood" $j$ in year $t$ and PopTotal ${ }_{q, t}$ is the number of households in artificial neighborhood $q$ in year $t . \phi(j, q)$ is a weighting function and $\Phi_{j, t}$ is a normalization factor such that:

$$
\Phi_{j, t}=\sum_{q=1}^{n} \phi(j, q)
$$

We define $\phi(j, q)$, following Reardon et al. (2008):

$$
\phi_{j, q}= \begin{cases}{\left[1-\left(\frac{d(j, q)}{y}\right)^{2}\right]^{2}} & \text { if } d(j, q) \leq y \\ 0 & \text { if } d(j, q)>y\end{cases}
$$

where $d(j, q)$ is the euclidean distance between the centers of artificial neighborhoods $j$ and $q$.

We compute the number of Muslim and non-Muslim households in the local environment of each artificial neighborhood which we denote by PopM $_{\text {uslim }},\left(\right.$ PopNoñMuslim $\left._{j, t}\right)$ respectively using the same methodology. Using the same notation as in Reardon and O'Sullivan (2004) we define $\pi_{m}$ as the share of group $m$ in the city, $\pi_{q m}$ as the share of group $m$ inside "artificial neighborhood" $q$, and $\tilde{\pi}_{q m}$ as the share of group $m$ in the local environment of "artificial neighborhood" $q$. 
We are now able to define the spatial versions of the dissimilarity and isolation (for Muslims) indexes. The spatial dissimilarity index is defined as:

$$
\text { Dissimilarity }_{t}=\frac{1}{2} \sum_{k \in M, \bar{M}} \sum_{q=1}^{n} \frac{\text { PopTotal }_{q, t}}{\operatorname{PopTotal}_{t} \times I} \times\left|\tilde{\pi}_{q, k, t}-\pi_{k, t}\right|
$$

where $I$ is the "interaction index":

$$
I=\sum_{k \in M, \bar{M}} \pi_{k} \times\left(1-\pi_{k}\right)
$$

whereas the spatial isolation index is defined as:

$$
\text { Isolation }_{t}=\sum_{q=1}^{n} \frac{\text { PopMuslim }_{q, t}}{\text { PopMuslim }_{t}} \times \tilde{\pi}_{j, t}
$$




\section{Appendix C Results of the Robustness Checks}

In this section, we introduce the results of the following robustness checks:

1) we control for the change in the number of workers in state non-industrial jobs, 2) we employ an alternative dependent variable, the change in the number and proportion of mixed-religion streets, 3) we modify the control group to include only locations that did not have in their proximity any state firms in either 1848 or 1868,4$)$ we limit the sample to locations that lie within a 1-kilometer radius from the opening/closures of each type of industry, and alternatively, 5) we control for a polynomial in longitude and latitude, 6) we limit the sample to Muslim and Coptic Christian households only, and 7) we correct for more general forms of spatial correlation. 
Table C.1: Industrialization and Segregation: Controlling for Workers in State Non-Industrial Jobs

(a) Change in Isolation

\begin{tabular}{|c|c|c|c|c|}
\hline & $\begin{array}{c}\Delta \text { Isolation } \\
(1) \\
300 \text { meters } \\
\end{array}$ & $\begin{array}{l}\text { uslim households } \\
(2) \\
500 \text { meters }\end{array}$ & $\begin{array}{c}\begin{array}{l}\text { Isolation } \\
(3) \\
300 \text { meters }\end{array} \\
\end{array}$ & $\begin{array}{l}\text { Muslim households } \\
\text { (4) } \\
500 \text { meters }\end{array}$ \\
\hline$=1$ if all textile state firms closed $(500 \mathrm{~m}$ radius $)$ & $\begin{array}{c}-0.053^{* * *} \\
(0.015)\end{array}$ & $\begin{array}{c}-0.021^{* *} \\
(0.007)\end{array}$ & $\begin{array}{c}0.088^{* * *} \\
(0.021)\end{array}$ & $\begin{array}{c}0.028^{* * *} \\
(0.007)\end{array}$ \\
\hline$=1$ if railways station opened $(500 \mathrm{~m}$ radius $)$ & $\begin{array}{c}0.108^{* * *} \\
(0.023)\end{array}$ & $\begin{array}{c}0.156^{* * *} \\
(0.035)\end{array}$ & $\begin{array}{c}-0.086^{* * *} \\
(0.023)\end{array}$ & $\begin{array}{c}-0.144^{\text {**** }} \\
(0.034)\end{array}$ \\
\hline Controls & Yes & Yes & Yes & Yes \\
\hline Workers in state non-industrial jobs & Yes & Yes & Yes & Yes \\
\hline Clusters & 137 & 138 & 94 & 125 \\
\hline Locations & 918 & 921 & 505 & 747 \\
\hline $\mathrm{R} 2$ & 0.286 & 0.464 & 0.417 & 0.523 \\
\hline
\end{tabular}

(b) Population Changes - Locations with at Least One Muslim Household

\begin{tabular}{|c|c|c|c|c|}
\hline & $\begin{array}{c}\begin{array}{c}\Delta \text { Number } \\
(1) \\
300 \text { meters }\end{array} \\
\end{array}$ & $\begin{array}{l}\text { uslim households } \\
(2) \\
500 \text { meters } \\
\end{array}$ & $\begin{array}{c}\Delta \text { Number } \\
(3) \\
300 \text { meters } \\
\end{array}$ & $\begin{array}{l}\text { Muslim households } \\
\text { (4) } \\
500 \text { meters }\end{array}$ \\
\hline$=1$ if all textile state firms closed ( $500 \mathrm{~m}$ radius) & $\begin{array}{c}-1.779 \\
(11.477)\end{array}$ & $\begin{array}{c}0.561 \\
(11.442)\end{array}$ & $\begin{array}{l}1.712 \\
(1.285)\end{array}$ & $\begin{array}{c}13.133^{* * *} \\
(2.590)\end{array}$ \\
\hline$=1$ if railways station opened (500m radius) & $\begin{array}{c}13.397 \\
(17.096)\end{array}$ & $\begin{array}{l}66.231^{* *} \\
(28.661)\end{array}$ & $\begin{array}{l}-0.966 \\
(1.778)\end{array}$ & $\begin{array}{c}-23.009^{* * *} \\
(6.035)\end{array}$ \\
\hline Controls & Yes & Yes & Yes & Yes \\
\hline Workers in state non-industrial jobs & Yes & Yes & Yes & Yes \\
\hline Clusters & 137 & 138 & 137 & 138 \\
\hline Locations & 918 & 921 & 918 & 921 \\
\hline $\mathrm{R} 2$ & 0.513 & 0.753 & 0.455 & 0.509 \\
\hline
\end{tabular}

(c) Population Changes - Locations with at Least One Non-Muslim Household

\begin{tabular}{|c|c|c|c|c|}
\hline & \multicolumn{2}{|c|}{$\begin{array}{l}\Delta \text { Number of Muslim households } \\
\begin{array}{l}(1) \\
300 \text { meters }\end{array} \\
\text { (2) } \\
\end{array}$} & \multicolumn{2}{|c|}{$\begin{array}{l}\Delta \text { Number of non-Muslim households } \\
(3) \\
300 \text { meters }\end{array}$} \\
\hline$=1$ if all textile state firms closed $(500 \mathrm{~m}$ radius $)$ & $\begin{array}{c}-29.636^{* *} \\
(14.651)\end{array}$ & $\begin{array}{l}-19.029^{*} \\
(10.441)\end{array}$ & $\begin{array}{c}3.566 \\
(2.173)\end{array}$ & $\begin{array}{c}14.601^{* * *} \\
(2.392)\end{array}$ \\
\hline$=1$ if railways station opened $(500 \mathrm{~m}$ radius $)$ & $\begin{array}{l}-14.210 \\
(23.011)\end{array}$ & $\begin{array}{c}6.280 \\
(28.550)\end{array}$ & $\begin{array}{l}-3.731^{*} \\
(2.024)\end{array}$ & $\begin{array}{c}-26.047^{* * *} \\
(6.182)\end{array}$ \\
\hline Controls & Yes & Yes & Yes & Yes \\
\hline Workers in state non-industrial jobs & Yes & Yes & Yes & Yes \\
\hline Clusters & 94 & 125 & 94 & 125 \\
\hline Locations & 505 & 747 & 505 & 747 \\
\hline $\mathrm{R} 2$ & 0.696 & 0.812 & 0.529 & 0.542 \\
\hline
\end{tabular}

Source: Cairo's panel sample of locations that are observed in both 1848 and 1868 and defined using the 300 and 500 meters radii. Those are based on the 1848 and 1868 geocoded population census samples of Cairo aggregated to the household level and matched with information on locations of large state firms and other controls.

Notes: $* p<0.1, * * p<0.05, * * * p<0.01$. Standard errors clustered at the quarter level according to the

1848-census boundaries are in parentheses. 
Table C.2: Industrialization and Segregation: Alternative Segregation Measure

\begin{tabular}{|c|c|c|c|c|}
\hline & $\begin{array}{c}\begin{array}{c}\text { Number } \\
(1) \\
300 \text { meters }\end{array} \\
\end{array}$ & $\begin{array}{c}\text { mixed streets } \\
(2) \\
500 \text { meters }\end{array}$ & $\begin{array}{c}\Delta \text { Proportio } \\
(3) \\
300 \text { meters }\end{array}$ & $\begin{array}{l}\text { f mixed streets } \\
(4) \\
500 \text { meters }\end{array}$ \\
\hline$=1$ if all textile state firms closed $(500 \mathrm{~m}$ radius $)$ & $\begin{array}{l}-0.120 \\
(0.425)\end{array}$ & $\begin{array}{c}0.631 \\
(0.621)\end{array}$ & $\begin{array}{l}-0.005 \\
(0.026)\end{array}$ & $\begin{array}{l}-0.015 \\
(0.016)\end{array}$ \\
\hline$=1$ if railways station opened $(500 \mathrm{~m}$ radius $)$ & $\begin{array}{c}-2.790^{* * *} \\
(0.636)\end{array}$ & $\begin{array}{c}-7.914^{* * *} \\
(1.787)\end{array}$ & $\begin{array}{c}-0.145^{* *} \\
(0.050)\end{array}$ & $\begin{array}{c}-0.259^{* * *} \\
(0.062)\end{array}$ \\
\hline Controls & Yes & Yes & Yes & Yes \\
\hline Clusters & 137 & 138 & 137 & 138 \\
\hline Locations & 918 & 921 & 918 & 921 \\
\hline $\mathrm{R} 2$ & 0.567 & 0.696 & 0.417 & 0.560 \\
\hline
\end{tabular}

Source: Cairo's panel sample of locations that are observed in both 1848 and 1868 and defined using the 300 and 500 meters radii. Those are based on the 1848 and 1868 geocoded population census samples of Cairo aggregated to the household level and matched with information on locations of large state firms and other controls.

Notes: $* p<0.1, * * p<0.05, * * * p<0.01$. Standard errors clustered at the quarter level according to the

1848-census boundaries are in parentheses. Mixed-religion streets are those that have at least one Muslim household and one non-Muslim household. 
Table C.3: Industrialization and Segregation: Controlling for Type 3 Locations

(a) Change in Isolation

\begin{tabular}{lcccc}
\hline \hline & $\Delta$ Isolation of Muslim households & \multicolumn{2}{c}{ Isolation of non-Muslim households } \\
& $(1)$ & $(2)$ & $(3)$ & $(4)$ \\
& 300 meters & 500 meters & 300 meters & 500 meters \\
\hline =1 if all textile state firms closed (500m radius) & $-0.054^{* * *}$ & $-0.022^{* *}$ & $0.090^{* * *}$ & $0.030^{* * *}$ \\
& $(0.014)$ & $(0.007)$ & $(0.021)$ & $(0.007)$ \\
$=1$ if railways station opened (500m radius) & $0.111^{* * *}$ & $0.159^{* * *}$ & $-0.090^{* * *}$ & $-0.147^{* * *}$ \\
& $(0.022)$ & $(0.036)$ & $(0.022)$ & $(0.036)$ \\
Industrialized in both 1848 and 1868 & -0.015 & -0.001 & -0.020 & -0.000 \\
& $(0.013)$ & $(0.007)$ & $(0.018)$ & $(0.008)$ \\
Controls & & & & Yes \\
\hline Clusters & Yes & Yes & 94 & 125 \\
Locations & 137 & 138 & 505 & 747 \\
R2 & 918 & 921 & 0.416 & 0.512 \\
\hline \hline
\end{tabular}

(b) Population Changes - Locations with at Least One Muslim Household

\begin{tabular}{|c|c|c|c|c|}
\hline & $\begin{array}{l}\Delta \text { Number } \\
(1) \\
300 \text { meters }\end{array}$ & $\begin{array}{l}\text { slim households } \\
(2) \\
500 \text { meters }\end{array}$ & $\begin{array}{c}\Delta \text { Number } \\
(3) \\
300 \text { meters }\end{array}$ & $\begin{array}{l}\text { Muslim households } \\
\text { (4) } \\
500 \text { meters }\end{array}$ \\
\hline$=1$ if all textile state firms closed ( $500 \mathrm{~m}$ radius) & $\begin{array}{c}-6.257 \\
(13.710)\end{array}$ & $\begin{array}{l}-21.489 \\
(20.463)\end{array}$ & $\begin{array}{c}1.551 \\
(1.370)\end{array}$ & $\begin{array}{c}12.589^{* * *} \\
(2.744)\end{array}$ \\
\hline$=1$ if railways station opened ( $500 \mathrm{~m}$ radius $)$ & $\begin{array}{l}42.949^{* *} \\
(16.689)\end{array}$ & $\begin{array}{l}116.201^{*} \\
(64.027)\end{array}$ & $\begin{array}{l}-0.176 \\
(1.908)\end{array}$ & $\begin{array}{l}-21.592^{* * *} \\
(5.280)\end{array}$ \\
\hline Industrialized in both 1848 and 1868 & $\begin{array}{l}-24.692^{*} \\
(13.253)\end{array}$ & $\begin{array}{c}-44.549^{* *} \\
(19.936)\end{array}$ & $\begin{array}{c}-2.146^{* *} \\
(1.036)\end{array}$ & $\begin{array}{c}0.340 \\
(1.934)\end{array}$ \\
\hline Controls & Yes & Yes & Yes & Yes \\
\hline Clusters & 137 & 138 & 137 & 138 \\
\hline Locations & 918 & 921 & 918 & 921 \\
\hline $\mathrm{R} 2$ & 0.411 & 0.589 & 0.501 & 0.518 \\
\hline
\end{tabular}

(c) Population Changes - Locations with at Least One Non-Muslim Household

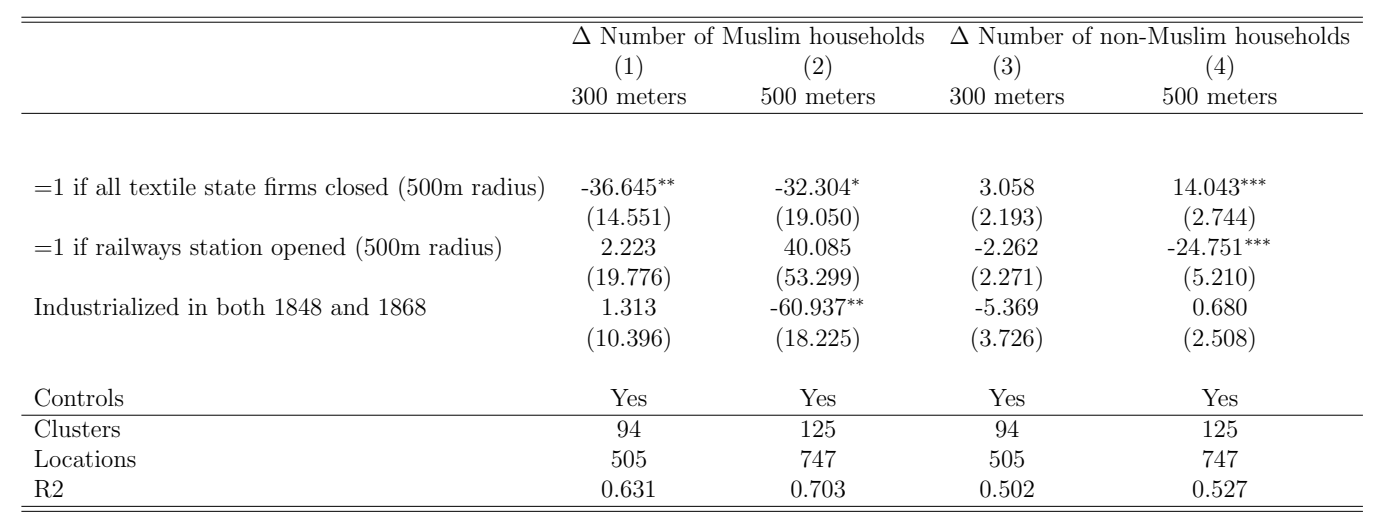

Source: Cairo's panel sample of locations that are observed in both 1848 and 1868 and defined using the 300 and 500 meters radii. Those are based on the 1848 and 1868 geocoded population census samples of Cairo aggregated to the household level and matched with information on locations of large state firms and other controls.

Notes: $* p<0.1, * * p<0.05, * * * p<0.01$. Standard errors clustered at the quarter level according to the 1848-census boundaries are in parentheses. 
Table C.4: Industrialization and Segregation: Closures of Textiles Firms and Limiting Sample to a 1-Kilometer Radius

(a) Change in Isolation

\begin{tabular}{|c|c|c|c|c|}
\hline & $\begin{array}{l}\Delta \text { Isolation } \\
\quad(1) \\
300 \text { meters }\end{array}$ & $\begin{array}{l}\text { uslim households } \\
(2) \\
500 \text { meters }\end{array}$ & $\begin{array}{c}\Delta \text { Isolation } \\
(3) \\
300 \text { meters }\end{array}$ & $\begin{array}{l}\text { Muslim households } \\
\text { (4) } \\
500 \text { meters }\end{array}$ \\
\hline$=1$ if all textile state firms closed $(500 \mathrm{~m}$ radius $)$ & $\begin{array}{c}-0.037^{* *} \\
(0.012)\end{array}$ & $\begin{array}{c}-0.025^{* * *} \\
(0.006)\end{array}$ & $\begin{array}{l}0.064^{* *} \\
(0.019)\end{array}$ & $\begin{array}{c}0.027^{* * *} \\
(0.007)\end{array}$ \\
\hline Controls & Yes & Yes & Yes & Yes \\
\hline Clusters & 70 & 70 & 49 & 63 \\
\hline Locations & 463 & 463 & 279 & 382 \\
\hline $\mathrm{R} 2$ & 0.257 & 0.339 & 0.407 & 0.391 \\
\hline
\end{tabular}

(b) Population Changes - Locations with at Least One Muslim Household

\begin{tabular}{|c|c|c|c|c|}
\hline & $\begin{array}{l}\Delta \text { Number } \\
(1) \\
300 \text { meters }\end{array}$ & $\begin{array}{l}\text { islim households } \\
(2) \\
500 \text { meters }\end{array}$ & $\begin{array}{l}\Delta \text { Number } \\
(3) \\
300 \text { meters }\end{array}$ & $\begin{array}{l}\text { Muslim households } \\
\text { (4) } \\
500 \text { meters }\end{array}$ \\
\hline$=1$ if all textile state firms closed (500m radius) & $\begin{array}{c}0.397 \\
(11.817)\end{array}$ & $\begin{array}{c}-0.448 \\
(16.946)\end{array}$ & $\begin{array}{c}1.850 \\
(1.282)\end{array}$ & $\begin{array}{c}13.843^{* * *} \\
(2.854)\end{array}$ \\
\hline Controls & Yes & Yes & Yes & Yes \\
\hline Clusters & 70 & 70 & 70 & 70 \\
\hline Locations & 463 & 463 & 463 & 463 \\
\hline $\mathrm{R} 2$ & 0.424 & 0.587 & 0.465 & 0.478 \\
\hline
\end{tabular}

(c) Population Changes - Locations with at Least One Non-Muslim Household

\begin{tabular}{|c|c|c|c|c|}
\hline & \multicolumn{2}{|c|}{$\begin{array}{l}\Delta \text { Number of Muslim households } \\
\begin{array}{l}(1) \\
300 \text { meters }\end{array} \quad \text { (2) } \\
\text { (1) meters }\end{array}$} & \multicolumn{2}{|c|}{$\Delta$ Number of non-Muslim households } \\
\hline$=1$ if all textile state firms closed $(500 \mathrm{~m}$ radius $)$ & $\begin{array}{c}-29.012^{* *} \\
(14.142)\end{array}$ & $\begin{array}{l}-23.237 \\
(14.550)\end{array}$ & $\begin{array}{l}4.535^{*} \\
(2.449)\end{array}$ & $\begin{array}{c}13.884^{* * *} \\
(3.049)\end{array}$ \\
\hline Controls & Yes & Yes & Yes & Yes \\
\hline Clusters & 49 & 63 & 49 & 63 \\
\hline Locations & 279 & 382 & 279 & 382 \\
\hline $\mathrm{R} 2$ & 0.680 & 0.732 & 0.492 & 0.472 \\
\hline
\end{tabular}

Source: Cairo's panel sample of locations that are observed in both 1848 and 1868 and defined using the 300 and 500 meters radii. Those are based on the 1848 and 1868 geocoded population census samples of Cairo aggregated to the household level and matched with information on locations of large state firms and other controls.

Notes: $* p<0.1, * * p<0.05, * * * p<0.01$. Standard errors clustered at the quarter level according to the Notes: $* p<0.1, * * p<0.05, * * * p<0.01$ 
Table C.5: Industrialization and Segregation: Opening of the Railway Station and Limiting Sample to a 1-Kilometer Radius

(a) Change in Isolation

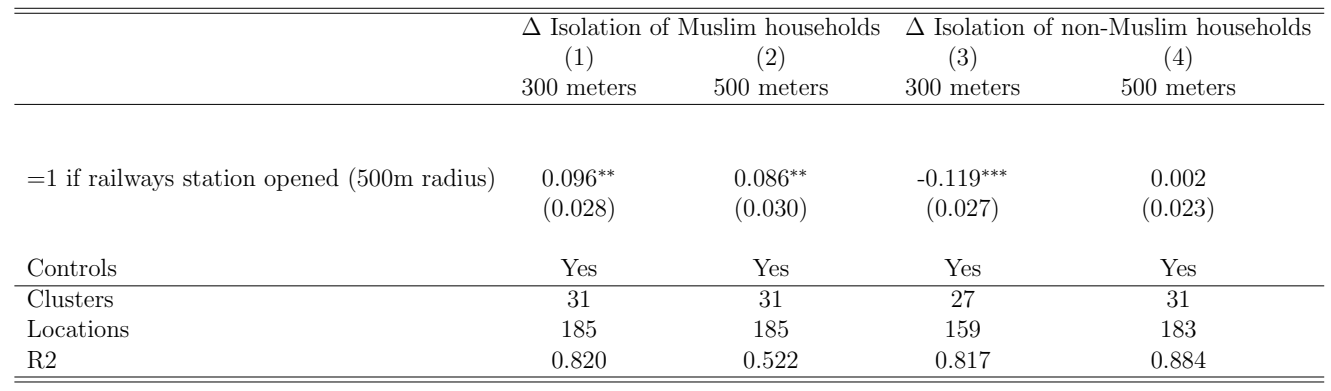

(b) Population Changes - Locations with at Least One Muslim Household

\begin{tabular}{|c|c|c|c|c|}
\hline & $\begin{array}{l}\Delta \text { Number c } \\
(1) \\
300 \text { meters }\end{array}$ & $\begin{array}{l}\text { islim households } \\
(2) \\
500 \text { meters }\end{array}$ & $\begin{array}{c}\Delta \text { Number } \\
(3) \\
300 \text { meters }\end{array}$ & $\begin{array}{l}\text { Muslim households } \\
\text { (4) } \\
500 \text { meters }\end{array}$ \\
\hline$=1$ if railways station opened (500m radius) & $\begin{array}{c}21.404 \\
(15.719)\end{array}$ & $\begin{array}{c}23.497 \\
(46.584)\end{array}$ & $\begin{array}{l}-2.844 \\
(2.014)\end{array}$ & $\begin{array}{l}-0.839 \\
(7.138)\end{array}$ \\
\hline Controls & Yes & Yes & Yes & Yes \\
\hline Clusters & 31 & 31 & 31 & 31 \\
\hline Locations & 185 & 186 & 185 & 186 \\
\hline $\mathrm{R} 2$ & 0.810 & 0.906 & 0.682 & 0.822 \\
\hline
\end{tabular}

(c) Population Changes - Locations with at Least One Non-Muslim Household

\begin{tabular}{|c|c|c|c|c|}
\hline & \multicolumn{2}{|c|}{$\Delta$ Number of Muslim households } & \multicolumn{2}{|c|}{$\Delta$ Number of non-Muslim households } \\
\hline & (1) & $(2)$ & (3) & (4) \\
\hline & 300 meters & 500 meters & 300 meters & 500 meters \\
\hline$=1$ if railways station opened $(500 \mathrm{~m}$ radius $)$ & $\begin{array}{c}19.860 \\
(12.923)\end{array}$ & $\begin{array}{c}12.954 \\
(42.767)\end{array}$ & $\begin{array}{l}-1.883 \\
(2.393)\end{array}$ & $\begin{array}{l}-0.765 \\
(7.192)\end{array}$ \\
\hline Controls & Yes & Yes & Yes & Yes \\
\hline Clusters & 27 & 31 & 27 & 31 \\
\hline Locations & 159 & 183 & 159 & 183 \\
\hline $\mathrm{R} 2$ & 0.862 & 0.916 & 0.675 & 0.820 \\
\hline
\end{tabular}

Source: Cairo's panel sample of locations that are observed in both 1848 and 1868 and defined using the 300 and 500 meters radii. Those are based on the 1848 and 1868 geocoded population census samples of Cairo aggregated to the household level and matched with information on locations of large state firms and other controls.

Notes: $* p<0.1, * * p<0.05, * * * p<0.01$. Standard errors clustered at the quarter level according to the Notes: $* p<0.1, * * p<0.05, * * * p<0$
1848 -census boundaries are in parentheses. 
Table C.6: Industrialization and Segregation: Controlling for a Polynomial in Longitude and Latitude

(a) Change in Isolation

\begin{tabular}{|c|c|c|c|c|}
\hline & $\begin{array}{c}\begin{array}{c}\text { Isolation } \\
(1) \\
300 \text { meters }\end{array} \\
\end{array}$ & $\begin{array}{l}\text { slim households } \\
(2) \\
500 \text { meters }\end{array}$ & $\begin{array}{c}\Delta \text { Isolation } \\
(3) \\
300 \text { meters }\end{array}$ & $\begin{array}{l}\text { Muslim households } \\
\text { (4) } \\
500 \text { meters }\end{array}$ \\
\hline$=1$ if all textile state firms closed (500m radius) & $\begin{array}{c}-0.047^{* *} \\
(0.014)\end{array}$ & $\begin{array}{c}-0.017^{* *} \\
(0.007)\end{array}$ & $\begin{array}{c}0.077^{* * *} \\
(0.020)\end{array}$ & $\begin{array}{l}0.023^{* *} \\
(0.007)\end{array}$ \\
\hline$=1$ if railways station opened (500m radius) & $\begin{array}{c}0.137^{* * *} \\
(0.018)\end{array}$ & $\begin{array}{c}0.172^{* * *} \\
(0.022)\end{array}$ & $\begin{array}{c}-0.143^{* * *} \\
(0.019)\end{array}$ & $\begin{array}{c}-0.173^{* * *} \\
(0.023)\end{array}$ \\
\hline Second order polynomial of latitude longitude & Yes & Yes & Yes & Yes \\
\hline Clusters & 137 & 138 & 94 & 125 \\
\hline Locations & 918 & 921 & 505 & 747 \\
\hline $\mathrm{R} 2$ & 0.250 & 0.436 & 0.354 & 0.480 \\
\hline
\end{tabular}

(b) Population Changes - Locations with at Least One Muslim Household

\begin{tabular}{|c|c|c|c|c|}
\hline & $\begin{array}{l}\Delta \text { Number } \\
(1) \\
300 \text { meters } \\
\end{array}$ & $\begin{array}{l}\text { uslim households } \\
(2) \\
500 \text { meters } \\
\end{array}$ & $\begin{array}{c}\Delta \text { Number } \\
(3) \\
300 \text { meters } \\
\end{array}$ & $\begin{array}{l}\text { Muslim households } \\
\text { (4) } \\
500 \text { meters }\end{array}$ \\
\hline$=1$ if all textile state firms closed (500m radius) & $\begin{array}{l}-10.749 \\
(14.268)\end{array}$ & $\begin{array}{l}-16.745 \\
(20.990)\end{array}$ & $\begin{array}{l}4.303^{*} \\
(2.335)\end{array}$ & $\begin{array}{c}15.249^{* * *} \\
(2.725)\end{array}$ \\
\hline$=1$ if railways station opened $(500 \mathrm{~m}$ radius $)$ & $\begin{array}{l}26.632^{* *} \\
(13.446)\end{array}$ & $\begin{array}{l}17.282 \\
(21.901)\end{array}$ & $\begin{array}{c}12.894^{* * *} \\
(2.685)\end{array}$ & $\begin{array}{c}21.641^{* * *} \\
(3.790)\end{array}$ \\
\hline Second order polynomial of latitude longitude & Yes & Yes & Yes & Yes \\
\hline Clusters & 137 & 138 & 137 & 138 \\
\hline Locations & 918 & 921 & 918 & 921 \\
\hline $\mathrm{R} 2$ & 0.289 & 0.434 & 0.136 & 0.282 \\
\hline
\end{tabular}

(c) Population Changes - Locations with at Least One Non-Muslim Household

\begin{tabular}{|c|c|c|c|c|}
\hline & $\begin{array}{c}\Delta \text { Number } \\
(1) \\
300 \text { meters } \\
\end{array}$ & $\begin{array}{l}\text { islim households } \\
(2) \\
500 \text { meters } \\
\end{array}$ & $\begin{array}{c}\Delta \text { Number } \\
(3) \\
300 \text { meters } \\
\end{array}$ & $\begin{array}{l}\text { Muslim households } \\
\text { (4) } \\
500 \text { meters }\end{array}$ \\
\hline$=1$ if all textile state firms closed (500m radius) & $\begin{array}{c}-11.562 \\
(17.243)\end{array}$ & $\begin{array}{l}-31.075 \\
(19.704)\end{array}$ & $\begin{array}{l}8.673^{* *} \\
(3.427)\end{array}$ & $\begin{array}{c}16.289^{* * *} \\
(2.938)\end{array}$ \\
\hline$=1$ if railways station opened (500m radius) & $\begin{array}{l}32.231^{* *} \\
(14.975)\end{array}$ & $\begin{array}{c}25.776 \\
(18.821)\end{array}$ & $\begin{array}{c}14.485^{* * *} \\
(3.897)\end{array}$ & $\begin{array}{c}21.890^{* * *} \\
(4.457)\end{array}$ \\
\hline Second order polynomial of latitude longitude & Yes & Yes & Yes & Yes \\
\hline Clusters & 94 & 125 & 94 & 125 \\
\hline Locations & 505 & 747 & 505 & 747 \\
\hline $\mathrm{R} 2$ & 0.509 & 0.590 & 0.207 & 0.320 \\
\hline
\end{tabular}

Source: Cairo's panel sample of locations that are observed in both 1848 and 1868 and defined using the 300 and 500 meters radii. Those are based on the 1848 and 1868 geocoded population census samples of Cairo aggregated to the household level and matched with information on locations of large state firms and other controls.

Notes: $* p<0.1, * * p<0.05, * * * p<0.01$. Standard errors clustered at the quarter level according to the

1848-census boundaries are in parentheses. 
Table C.7: Industrialization and Segregation: Coptic and Muslim Households Only

(a) Change in Isolation

\begin{tabular}{|c|c|c|c|c|}
\hline & \multicolumn{2}{|c|}{$\Delta$ Isolation of Muslim households } & \multicolumn{2}{|c|}{ 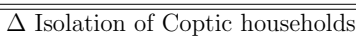 } \\
\hline & (1) & $(2)$ & (3) & (4) \\
\hline & 300 meters & 500 meters & 300 meters & 500 meters \\
\hline \multirow{2}{*}{$=1$ if all textile state firms closed ( $500 \mathrm{~m}$ radius) } & $-0.024^{* *}$ & -0.000 & $0.048^{* *}$ & 0.001 \\
\hline & $(0.011)$ & $(0.005)$ & $(0.017)$ & $(0.006)$ \\
\hline \multirow[t]{2}{*}{$=1$ if railways station opened (500m radius) } & $0.121^{* * *}$ & $0.171^{* * *}$ & $-0.114^{* * *}$ & $-0.138^{* * *}$ \\
\hline & $(0.013)$ & $(0.039)$ & $(0.019)$ & $(0.039)$ \\
\hline Controls & Yes & Yes & Yes & Yes \\
\hline Clusters & 137 & 138 & 74 & 102 \\
\hline Locations & 918 & 921 & 378 & 588 \\
\hline $\mathrm{R} 2$ & 0.355 & 0.497 & 0.528 & 0.580 \\
\hline
\end{tabular}

(b) Population Changes - Locations with at Least One Muslim Household

\begin{tabular}{|c|c|c|c|c|}
\hline & \multicolumn{2}{|c|}{$\begin{array}{l}\Delta \text { Number of Muslim households } \\
(1) \\
300 \text { meters } \\
\text { (2) }\end{array}$} & \multicolumn{2}{|c|}{$\begin{array}{l}\Delta \text { Number of Coptic households } \\
(3)\end{array}$} \\
\hline$=1$ if all textile state firms closed (500m radius) & $\begin{array}{c}-4.563 \\
(13.078)\end{array}$ & $\begin{array}{l}-17.225 \\
(19.023)\end{array}$ & $\begin{array}{l}-0.986 \\
(2.052)\end{array}$ & $\begin{array}{c}0.525 \\
(1.658)\end{array}$ \\
\hline$=1$ if railways station opened (500m radius) & $\begin{array}{l}35.568^{* *} \\
(12.182)\end{array}$ & $\begin{array}{c}59.707 \\
(51.124)\end{array}$ & $\begin{array}{c}3.917 \\
(4.563)\end{array}$ & $\begin{array}{c}-28.845^{* * *} \\
(6.361)\end{array}$ \\
\hline Controls & Yes & Yes & Yes & Yes \\
\hline Clusters & 137 & 138 & 137 & 138 \\
\hline Locations & 918 & 921 & 918 & 921 \\
\hline $\mathrm{R} 2$ & 0.410 & 0.584 & 0.560 & 0.601 \\
\hline
\end{tabular}

(c) Population Changes - Locations with at Least One Coptic Household

\begin{tabular}{|c|c|c|c|c|}
\hline & $\begin{array}{c}\begin{array}{c}\Delta \text { Number } \\
(1) \\
300 \text { meters }\end{array} \\
\end{array}$ & $\begin{array}{l}\text { uslim households } \\
(2) \\
500 \text { meters }\end{array}$ & $\begin{array}{c}\Delta \text { Number } \\
(3) \\
300 \text { meters }\end{array}$ & $\begin{array}{l}\text { pptic households } \\
(4) \\
500 \text { meters }\end{array}$ \\
\hline$=1$ if all textile state firms closed ( $500 \mathrm{~m}$ radius) & $\begin{array}{c}-37.631^{* *} \\
(11.083)\end{array}$ & $\begin{array}{c}-30.737^{*} \\
(15.846)\end{array}$ & $\begin{array}{c}-9.220^{* *} \\
(2.805)\end{array}$ & $\begin{array}{c}-0.493 \\
(1.961)\end{array}$ \\
\hline$=1$ if railways station opened (500m radius) & $\begin{array}{c}14.057 \\
(13.374)\end{array}$ & $\begin{array}{l}-43.057 \\
(42.003)\end{array}$ & $\begin{array}{l}-2.283 \\
(6.783)\end{array}$ & $\begin{array}{c}-30.644^{* * *} \\
(7.135)\end{array}$ \\
\hline Controls & Yes & Yes & Yes & Yes \\
\hline Clusters & 74 & 102 & 74 & 102 \\
\hline Locations & 378 & 588 & 378 & 588 \\
\hline $\mathrm{R} 2$ & 0.737 & 0.779 & 0.693 & 0.628 \\
\hline
\end{tabular}

Source: Cairo's panel sample of locations that are observed in both 1848 and 1868 and defined using the 300 and 500 meters radii. Those are based on the 1848 and 1868 geocoded population census samples of Cairo aggregated to the household level and matched with information on locations of large state firms and other controls.

Notes: $* p<0.1, * * p<0.05, * * * p<0.01$. Standard errors clustered at the quarter level according to the

1848-census boundaries are in parentheses. 
Table C.8: Industrialization and Segregation in 1848 and 1868: Estimation Using a Spatial Autoregressive Model (SAR)

(a) Change in Isolation

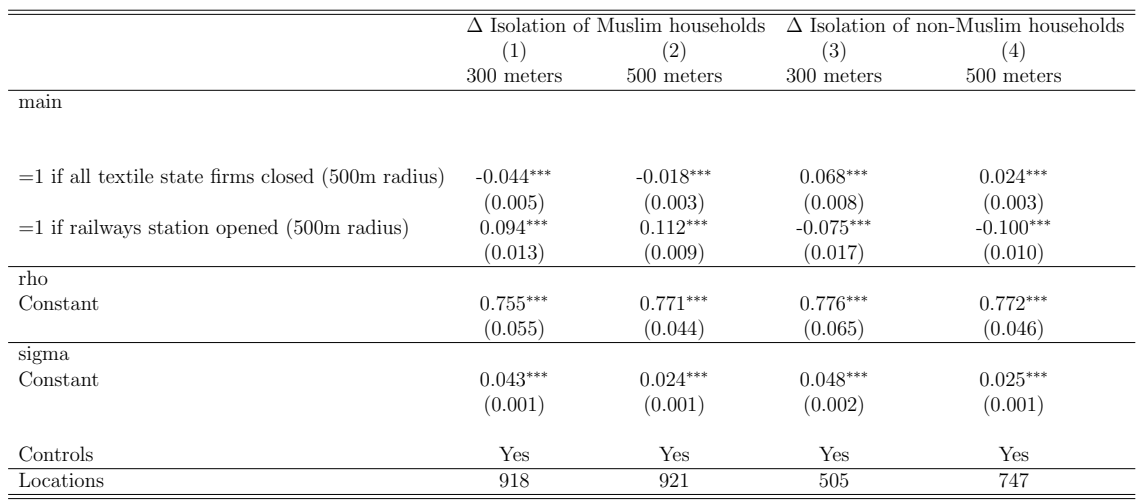

(b) Population Changes - Locations with at Least One Muslim Household

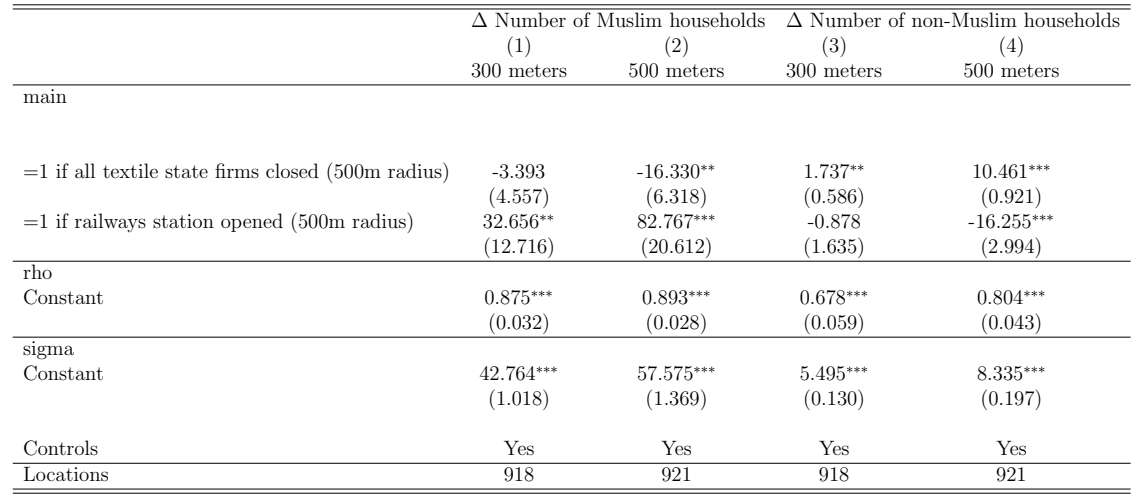

(c) Population Changes - Locations with at Least One Non-Muslim Household

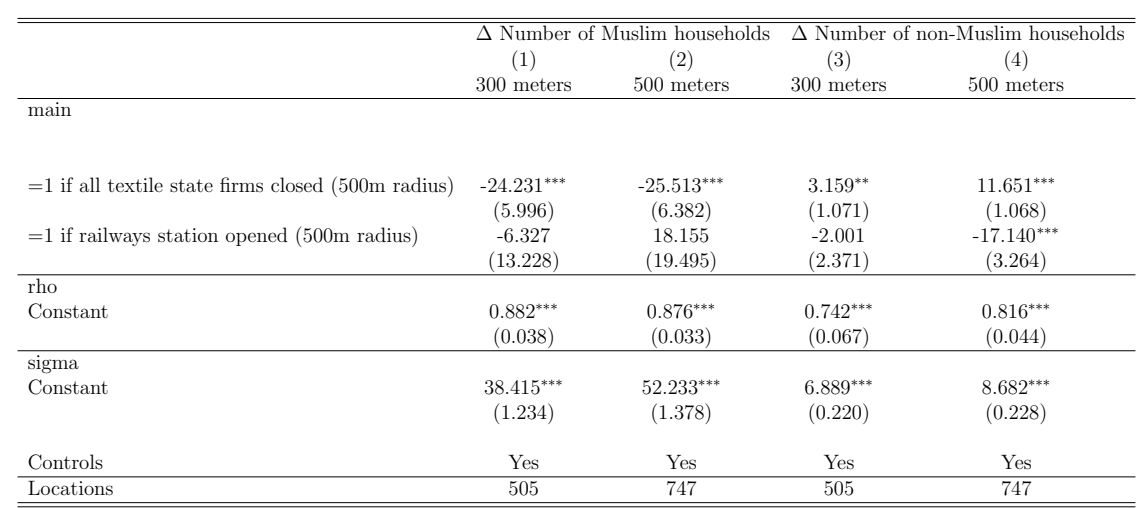

Source: Cairo's panel sample of locations that are observed in both 1848 and 1868 and defined using the 300 and 500 meters radii. Those are based on the 1848 and 1868 geocoded population census samples of Cairo aggregated to the household level and matched with information on locations of large state firms and other controls.

Notes: $* p<0.1, * * p<0.05, * * * p<0.01$. Standard errors are in parentheses. Regressions are estimated using an

SAR model where we control for the "spatially" lagged change in isolation (i.e. change in isolation in nearby locations) as an additional regressor in equation 2. The constant under "rho" refers to the coefficient of this additional regressor. 
Table C.9: Industrialization and Segregation in 1848 and 1868: Estimation Using a Spatial Error Model (SEM)

(a) Change in Isolation

\begin{tabular}{|c|c|c|c|c|}
\hline & \multicolumn{2}{|c|}{$\Delta$ Isolation of Muslim households } & $\begin{array}{c}\Delta \text { Isolation } \\
(3) \\
300 \text { meters }\end{array}$ & $\begin{array}{l}\text { Muslim households } \\
(4) \\
500 \text { meters }\end{array}$ \\
\hline main & & & & \\
\hline$=1$ if all textile state firms closed (500m radius) & $\begin{array}{c}-0.051^{* * *} \\
(0.005)\end{array}$ & $\begin{array}{c}-0.021^{* * *} \\
(0.003)\end{array}$ & $\begin{array}{c}0.082^{* * *} \\
(0.009)\end{array}$ & $\begin{array}{c}0.029^{* * *} \\
(0.004)\end{array}$ \\
\hline$=1$ if railways station opened (500m radius) & $\begin{array}{c}0.119^{* * *} \\
(0.015)\end{array}$ & $\begin{array}{c}0.118^{* * *} \\
(0.010)\end{array}$ & $\begin{array}{c}-0.117^{* * *} \\
(0.020) \\
\end{array}$ & $\begin{array}{c}-0.105^{* * *} \\
(0.011)\end{array}$ \\
\hline $\begin{array}{l}\text { lambda } \\
\text { Constant }\end{array}$ & $\begin{array}{c}0.778^{* * *} \\
(0.052)\end{array}$ & $\begin{array}{c}0.853^{* * *} \\
(0.036)\end{array}$ & $\begin{array}{c}0.812^{* * *} \\
(0.057)\end{array}$ & $\begin{array}{c}0.856^{* * *} \\
(0.038)\end{array}$ \\
\hline $\begin{array}{l}\text { sigma } \\
\text { Constant }\end{array}$ & $\begin{array}{c}0.043^{* * *} \\
(0.001)\end{array}$ & $\begin{array}{c}0.024^{* * *} \\
(0.001)\end{array}$ & $\begin{array}{c}0.047^{* * *} \\
(0.002)\end{array}$ & $\begin{array}{c}0.025^{* * *} \\
(0.001)\end{array}$ \\
\hline Controls & Yes & Yes & Yes & Yes \\
\hline Locations & 918 & 921 & 505 & 747 \\
\hline
\end{tabular}

(b) Population Changes - Locations with at Least One Muslim Household

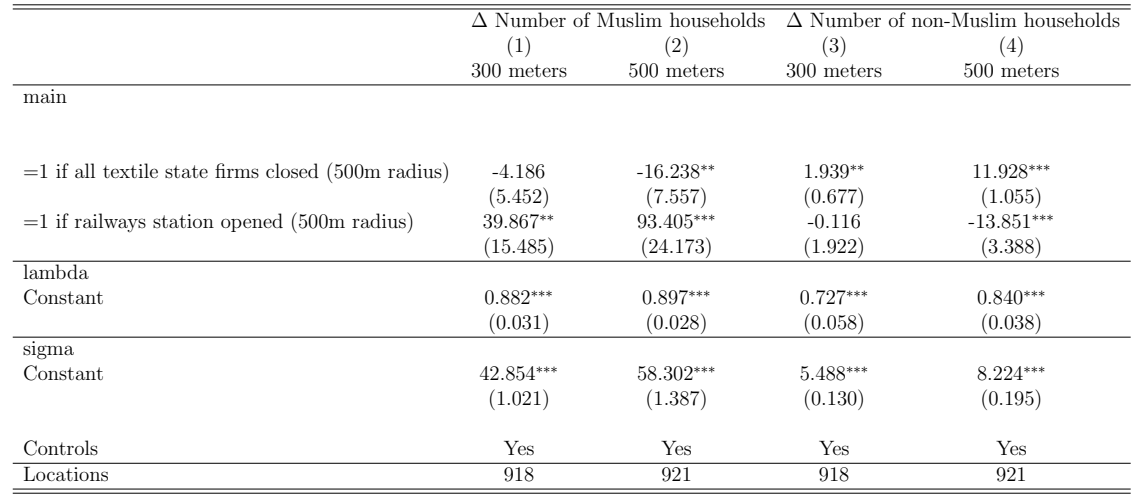

(c) Population Changes - Locations with at Least One Non-Muslim Household

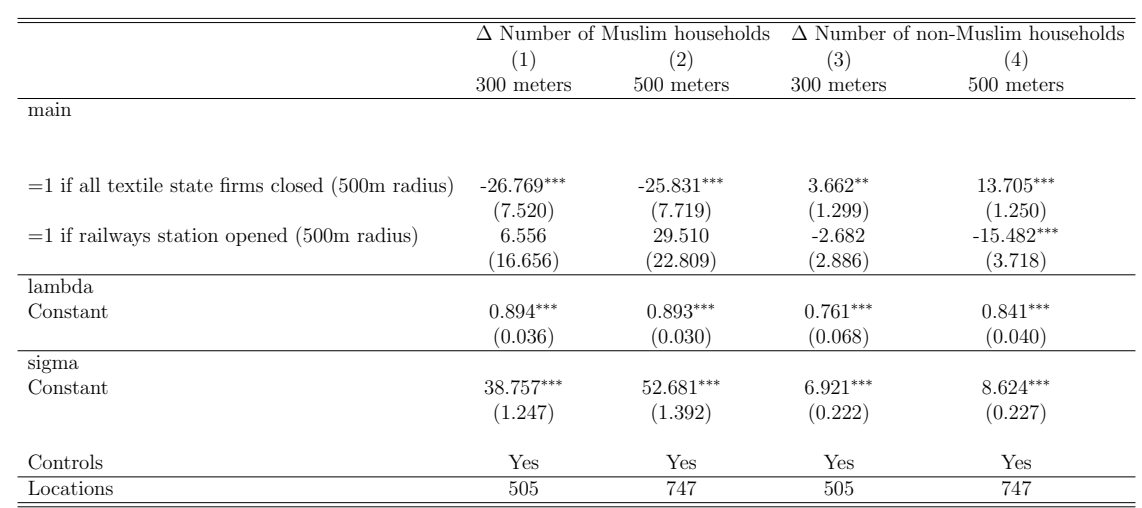

Source: Cairo's panel sample of locations that are observed in both 1848 and 1868 and defined using the 300 and 500 meters radii. Those are based on the 1848 and 1868 geocoded population census samples of Cairo aggregated to the household level and matched with information on locations of large state firms and other controls.

Notes: $* p<0.1, * * p<0.05, * * * p<0.01$. Standard errors are in parentheses. Regressions are estimated using an SEM model where we allow for spatial correlation in the error term. The constant under "lambda" refers to the coefficient of this additional regressor. 